\title{
Bioavailability of riverine dissolved organic matter in three Baltic Sea estuaries and the effect of catchment land use
}

\author{
E. Asmala ${ }^{1}$, R. Autio ${ }^{1}$, H. Kaartokallio ${ }^{1}$, L. Pitkänen ${ }^{2}$, C. A. Stedmon ${ }^{3}$, and D. N. Thomas ${ }^{1,4,5}$ \\ ${ }^{1}$ Marine Research Centre, Finnish Environment Institute (SYKE), Helsinki, Finland \\ ${ }^{2}$ University of Helsinki, Department of Food and Environmental Sciences, Helsinki, Finland \\ ${ }^{3}$ National Institute for Aquatic Resources, Section for Oceanography and Climate, Technical University of Denmark, \\ Charlottenlund, Denmark \\ ${ }^{4}$ School of Ocean Sciences, Bangor University, Menai Bridge, Anglesey, UK \\ ${ }^{5}$ Arctic Centre, Aarhus University, Aarhus, Denmark \\ Correspondence to: E. Asmala (eero.asmala@ymparisto.fi)
}

Received: 8 May 2013 - Published in Biogeosciences Discuss.: 18 June 2013

Revised: 19 September 2013 - Accepted: 1 October 2013 - Published: 5 November 2013

\begin{abstract}
The microbial degradation of dissolved organic carbon and nitrogen (DOC, DON) was studied in three Finnish boreal estuaries with contrasting land use patterns (Kiiminkijoki - natural forest and peatland; Kyrönjoki agricultural; Karjaanjoki - mixed/urban). Bioassays of 12$18 \mathrm{~d}$ long durations were used in 3 seasons at in situ temperatures. Besides the bulk parameters, a suite of dissolved organic matter (DOM) quality parameters were also investigated, including colored DOM (CDOM), fluorescent DOM and the molecular weight of DOM. Bioavailable DOC and DON pools varied significantly between the estuaries, from 7.9 to $10.6 \%$ and from 5.5 to $21.9 \%$, respectively. DOM originating from the catchment dominated by natural forests and peatlands (Kiiminkijoki) had the lowest DOC and DON degradation rates, as well as the lowest proportions of biodegradable DOC and DON. A greater proportion of agricultural land in the catchment increased the bioavailability of DON, but not the bioavailability of DOC (Kyrönjoki). Additionally, DOM quality varied significantly between the estuaries, and DOM originating from the agricultural Kyrönjoki catchment sustained higher DOC and DON degradation rates and higher bacterial growth efficiency (BGE) compared to those of the natural forest and peat dominated Kiiminkijoki catchment. The quality of DOM, indicated by differences in CDOM, fluorescent DOM and molecular weight, varied between estuaries with differing land use and was concluded to be major driver of BGE of these systems and thereafter to the microbial $\mathrm{CO}_{2}$ fluxes from the estuaries. The differ-
\end{abstract}

ences in BGE resulted in a 5-fold difference in the calculated daily bacterial $\mathrm{CO}_{2}$ emissions between the study's estuaries due to bacterial activity, ranging from $40 \mathrm{~kg} \mathrm{Cd}^{-1}$ in the Karjaanjoki estuary to $200 \mathrm{~kg} \mathrm{C} \mathrm{d}^{-1}$ in the Kyrönjoki estuary. Lower DOC : DON ratios, smaller molecular weight and higher CDOM absorption spectral slope values of DOM resulted in higher proportion of the initial DOC and DON being transferred to microbial growth and therefore to the pelagic food web. The pristine, peatland and forest-dominated $\mathrm{Ki}$ iminkijoki catchment had the lowest BGE, and therefore proportionally highest $\mathrm{CO}_{2}$ fluxes.

\section{Introduction}

Organic matter consists of particulate and dissolved phases (POM and DOM), which are traditionally separated on the rather arbitrary criteria of filter pore sizes typically ranging between 0.1 and $0.7 \mu \mathrm{m}$. POM and DOM in aquatic systems are either derived from organisms within the system (autochthonous) or transported into the system via rivers and atmospheric deposition (allochthonous). The DOM pool is vital for the functioning of food webs in aquatic systems since it forms the basis for heterotrophic activity and its breakdown is central to the regeneration of inorganic nutrients (Hansell and Carlsson, 2002; Søndergaard and Thomas, 2004). 
Rivers and estuaries link terrestrial systems and the oceans, and rivers are a major source of allochthonous carbon to the global ocean, transporting an estimated $0.25 \mathrm{Gt}$ of dissolved organic carbon (DOC) annually (Hedges et al., 1997; Jiao et al., 2010). Nitrogen fluxes from terrestrial systems to aquatic systems generally increase with greater degree of anthropogenic disturbance to a catchment (Stedmon et al., 2006), and presently anthropogenically induced fluxes of nitrogen exceed natural fluxes globally (Vitousek et al., 1997). These fluxes of both organic carbon and nitrogen are essential to the overall productivity of estuarine ecosystems since they are the basis of the heterotrophic food webs (Mann, 1988).

Variation in DOM quality can explain up to $75 \%$ of the variability of bacterial growth in estuarine waters (Hopkinson et al., 1998). Bacterial growth efficiency (BGE) describes the proportion of carbon that heterotrophic bacterial cells transfer from substrate (DOM) to biomass (del Giorgio and Cole, 1998) and can be used as a metric to characterize bacterial DOM utilization. The quantity of DOM, as a substrate for heterotrophs, has been shown to affect BGE only at very low concentrations (Eiler et al., 2003), whereas the quality of DOM has a stronger influence on BGE, e.g., the DOC: DON (dissolved organic nitrogen) ratio is typically inversely proportional to BGE (Kroer, 1993). A range of other environmental variables have also been reported to affect BGE, including temperature, inorganic nutrient availability, salinity and the DOM source (del Giorgio and Cole, 1998; Wikner et al., 1999).

The DOM pool can be investigated by studying the absorbance and fluorescence properties of its colored fraction (CDOM). Even though absorbance and fluorescence analyses only measure directly a portion of the DOM pool, these relatively quick and non-destructive measurements reveal details of the whole DOM pool, both quantitatively and qualitatively (Nelson and Siegel, 2013). Absorption and fluorescence properties of CDOM have been linked to DOC concentration (Banoub 1973; Fichot and Benner 2011; Asmala et al., 2012; Mann et al., 2012), origin (McKnight et al., 2001; Stedmon and Markager, 2001; Baker and Spencer, 2004) and molecular size (Helms et al., 2008). The molecular size of DOM has implications for the bacterial utilization of the DOM, as generally larger molecules support higher bacterial growth and DOM utilization (Amon and Benner, 1996). The continuous degradation of large DOM molecules to smaller ones decreases the bioavailability of DOM, creating a continuum where bioavailability in general decreases with DOM molecular size (Weiss and Simon, 1999).

Combining CDOM absorption measurements at $254 \mathrm{~nm}$ and DOC measurements, the resulting DOC-specific absorbance $\left(\mathrm{SUVA}_{254}\right)$ is a proxy of the DOC aromaticity, and is a valuable parameter for assessing the quality of the DOM pool (Weishaar et al., 2003). SUVA 254 has been shown to be inversely proportional to the biodegradability of DOM: increasing SUVA values indicate a more aromatic and less biodegradable DOM pool (Kalbitz et al., 2003a; Berggren et al., 2009). Also other optical properties, namely fluorescence properties of DOM, can be used to assess its bioavailability. Typically, bacterial degradation increases the amount of humic-like fluorescence in the DOM pool (Boyd and Osburn, 2004).

Land-use and land-cover changes have significant impacts on riverine, estuarine and coastal water chemistry (Johnes et al., 1996; Jickells, 1998; Sachse et al., 2005). Transport along the hydrological path - streams, rivers and lakes - changes the nature of the terrestrially derived DOM through photochemical oxidation and biological transformation (Bertilsson et al., 1999; Cory et al., 2013). Further, these changes affect the consequential degradation of DOM down an estuary (Sun et al., 1997). In boreal river systems, in general, during this transport the total organic carbon (TOC) concentrations decrease and total organic nitrogen (TON) concentrations increase, leading to decreasing TOC: TON ratios (Mattsson et al., 2005, Kortelainen et al., 2006). This applies to DOC and DON as well, since $94 \%$ of the TOC and $90 \%$ of the total nitrogen (TN) in boreal rivers are in dissolved forms (Mattsson et al., 2005). The retention time of DOM in the hydrological path decreases its bioavailability, and also decreases the total organic matter export from catchment area (Mattsson et al., 2005).

The quality of terrestrially derived DOM in aquatic systems varies between different land use in the catchments: DOM originating from forested and peatland areas typically has high $\mathrm{C}: \mathrm{N}$ ratios, up to 66 in boreal catchments (Kortelainen et al., 1997). This DOM pool is dominated by aromatic, humic-like compounds that are inferior substrates for heterotrophic utilization compared to non-humic compounds (Moran and Hodson, 1990; Hulatt et al., 2013). Agricultural soils on the other hand are sources of highly biodegradable DOM (Boyer and Groffman, 1996; Kalbitz et al., 2003b; van Kessel et al., 2009).

The relationship between DOM quality and bacterial growth efficiency is still understudied, and little is known about the influence of the catchment land use on estuarine DOM cycling, which ultimately influences the carbon balances of estuaries. To address these gaps in knowledge, the objectives of this study were (1) to measure the bioavailability of DOM to heterotrophic bacteria in three boreal estuaries influenced by contrasting land use; (2) to study the effects of catchment characteristics and seasonal variation on DOM biodegradability with combined effects of salinity and inorganic nutrient manipulations; and (3) to link the bioavailability to bulk characteristics of DOM determined by optical and molecular size characteristics. We hypothesize that the differences in land use are reflected in the quality (including bioavailability) of riverine DOM, and subsequently affect the carbon and nitrogen cycling in estuaries. 
Table 1. Properties of river catchments, average discharges $(Q)$, total organic carbon (TOC), total nitrogen (TN) and total phosphorus (TP) loadings during the study period. "Field" includes pasture and cropland, "open" consists of areas with no vegetation and "water" includes lakes, streams, etc. Discharge and loading values are from the database of Finnish Environment (HERTTA, 2012).

\begin{tabular}{lrrr}
\hline River & Karjaanjoki & Kyrönjoki & Kiiminkijoki \\
\hline Catchment area & 2046 & 4923 & 3814 \\
$\left(\mathrm{~km}^{2}\right)$ & & & \\
\hline Land use (\%) & & & \\
Urban & 10 & 5 & 2 \\
Field & 19 & 25 & 2 \\
Forest & 46 & 36 & 40 \\
Peatland & 3 & 19 & 40 \\
Open & 12 & 13 & 14 \\
Water & 11 & 1 & 3 \\
Mean $Q\left(\mathrm{~m}^{3} \mathrm{~s}^{-1}\right)$ & 15 & 37 & 44 \\
TOC loading $\left(\mathrm{t} \mathrm{yr}^{-1}\right)$ & 4037 & 25401 & 23490 \\
TN loading $\left(\mathrm{t} \mathrm{yr}^{-1}\right)$ & 378 & 2953 & 801 \\
TP loading $\left(\mathrm{t} \mathrm{yr}^{-1}\right)$ & 12 & 91 & 42 \\
\hline
\end{tabular}

\section{Material and methods}

\subsection{Study area, catchment characteristics}

The three study sites used were the Karjaanjoki, Kyrönjoki and Kiiminkijoki estuaries (Fig. 1). The three catchments draining to the estuaries have differing land use and consequently the estuaries have different nutrient loadings (Table 1). The Karjaanjoki catchment area is the most urbanized of the three, and has the lowest TOC and TN loadings of the rivers studied (2.0 and $0.18 \mathrm{t} \mathrm{yr}^{-1} \mathrm{~km}^{-2}$, respectively). The Kyrönjoki catchment is an agriculture-dominated catchment with both fertilized pastures and crops, resulting in high TOC and TN loadings (5.2 and $0.60 \mathrm{t} \mathrm{yr}^{-1} \mathrm{~km}^{-2}$, respectively). In contrast, the Kiiminkijoki catchment consists mostly of peatlands and forests, which results in high TOC and low TN loadings (6.2 and $0.21 \mathrm{t} \mathrm{yr}^{-1} \mathrm{~km}^{-2}$, respectively).

Samples from both the river and sea endmembers of each estuary were collected on four transect sampling trips, and a total of 24 samples were used for the experiments. Sampling campaigns took place in April/May, August, October 2010 and April/May 2011. The Karjaanjoki estuary was the longest of the study estuaries, the distance between river and sea endmember was $38 \mathrm{~km}$ and the salinity of the sea endmember was on average $6.3 \pm 0.5$. In the Kyrönjoki and Kiiminkijoki estuaries the endmembers were 36 and $21 \mathrm{~km}$ apart and salinity of the sea endmember samples were $2.7 \pm 1.1$ and $2.3 \pm 0.1$, respectively. In all cases the river waters were sampled from the main channels, near to the river mouths. The seawater samples were taken from the outer archipelago, where salinities are, or close to those, of the open-sea salinity values in the Baltic Sea. Surface waters were collected, using either a Limnos-type water sampler or

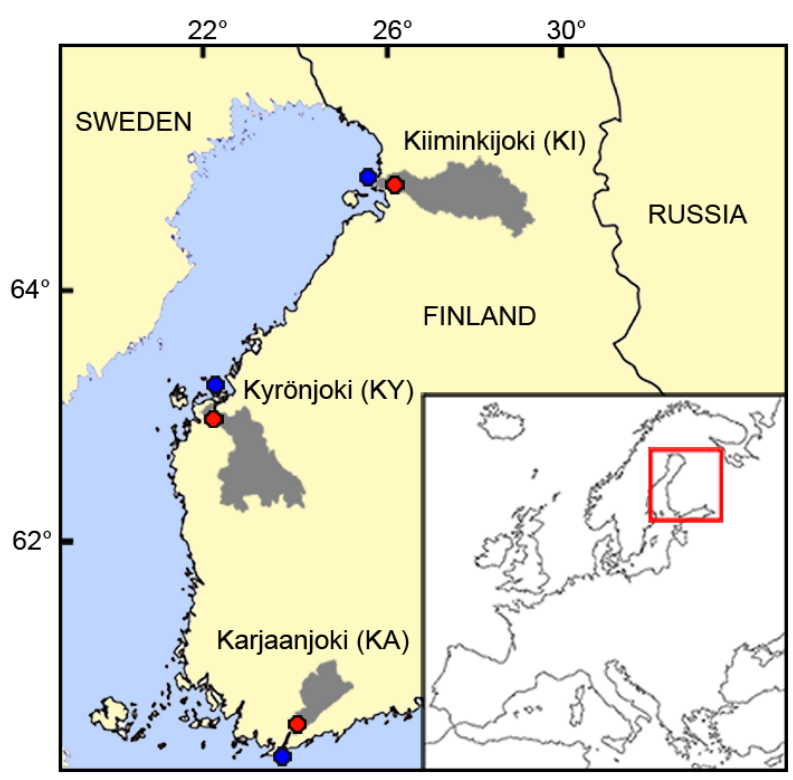

Fig. 1. Map showing the catchment areas (shaded grey) and the sampling locations of study estuaries. Red circles mark the sampling point of each river endmember, and blue circles the respective sea endmembers in the Baltic Sea basin.

polyethylene bucket. The samples were immediately transferred to $30 \mathrm{~L}$ polyethylene canisters and stored cool and dark until filtration in laboratory (within $24 \mathrm{~h}$ ).

\subsection{Experimental design}

With three estuaries each sampled on four occasions, altogether 12 individual experiments were carried out as illustrated in Fig. 2. Water for each experiment was first filtered through an $0.8 \mu \mathrm{m}$ cartridge filter (Sartoclean CA MidiCaps, Sartorius AG, Göttingen, Germany) to remove most of the particulate matter, including the bacteriovores. After filtration, in addition to the original endmember units a $1: 1 \mathrm{mix}$ of sea and river water was prepared, creating a three-point experimental gradient with both endmembers and the artificial middle point. Synthetic sea salt (Tropic Marin, Dr. Biener GMBH, Wartenberg, Germany) was added to a subset of mixed and river water to give a sub-series of these two waters with a salinity of the ambient seawater. The effect of salt addition was tested since there is evidence of salt-induced flocculation and transformation of DOM in estuaries (Sholkovitz et al., 1978; Abdulla et al., 2010). Also, changes in salinity have been observed to change growth characteristics of bacterial communities in the Baltic Sea estuaries (Langenheder et al., 2003).

The following day, a nutrient addition was made to subsets of the prepared experiment waters, with both nitrate $\left(\mathrm{NaNO}_{3}\right)$ and phosphate $\left(\mathrm{KH}_{2} \mathrm{PO}_{4}\right)$, to reach final concentrations of 5.5 and $1 \mu \mathrm{mol} \mathrm{L}{ }^{-1}$, respectively. If nutrient levels already exceeded these values, no additions were made. The 


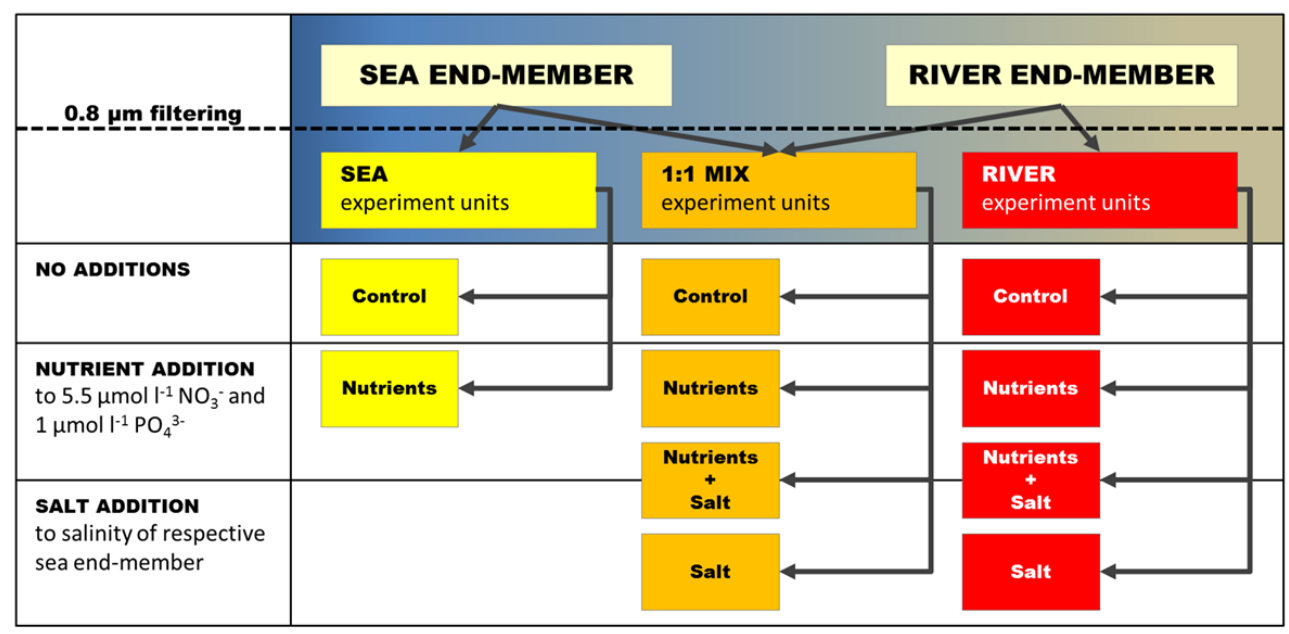

Fig. 2. Schematic representation of experiment design. The experiment following this scheme was repeated on all three estuaries on four different occasions, resulting in 12 individual experiments.

purpose of nutrient enrichment was to ensure replete nitrogen and phosphorus conditions during the degradation experiments. The combination of different water types (estuary endmembers; sea and river, and 1:1 mix of these) and treatments (salt and nutrient addition and the combination of those) created 10 different experiment units (no salt additions to sea units). The newly created experiment waters were left to settle for $3-4 \mathrm{~h}$ in order to let the units reach gas equilibrium after the physical disturbance and nutrient additions. Subsequently ten $250 \mathrm{~mL}$ glass bottles and 3 Winkler-type glass bottles were filled by careful siphoning from each unit. All bottles were submerged in a water bath, and were incubated between 12 and $18 \mathrm{~d}$ (variation in experiment durations due to logistic reasons) in the dark at the in situ temperature of the sampling sites $\left(4 \pm 2{ }^{\circ} \mathrm{C}\right.$ in spring, $18 \pm 2{ }^{\circ} \mathrm{C}$ in summer and $10 \pm 2{ }^{\circ} \mathrm{C}$ in autumn). These seasonal temperatures were used as incubation temperatures for all estuaries in each season.

On each sampling day, two $250 \mathrm{~mL}$ experiment bottles were pooled for further analyses. On every second sampling, also a Winkler-type bottle was taken for dissolved oxygen (DO) analysis. From the pooled samples, subsamples were taken for the following analyses: flow cytometry (FCM) samples were stored in $2 \mathrm{~mL}$ cryo-tubes and fixed with $0.2 \mu \mathrm{m}$ filtered electron microscopy-grade paraformaldehyde (final concentration of $1 \%$ ) and stored frozen at $-80^{\circ} \mathrm{C}$ until measurement. Inorganic nutrient analyses $\left(\mathrm{NH}_{4}^{+}, \mathrm{NO}_{2}^{-}, \mathrm{NO}_{3}^{-}\right.$, and $\mathrm{PO}_{4}^{3-}$ ) were done immediately after sampling. For analysis of properties of DOM, a portion of sample water was filtered through pre-combusted $\left(450^{\circ} \mathrm{C}\right.$ for $\left.4 \mathrm{~h}\right) 0.7 \mu \mathrm{m} \mathrm{GF} / \mathrm{F}$ (Whatman). The nominal pore size of GF/F filters decreases with the pre-combustion process reducing the particle cutoff size, thus making the selected filter more suitable for measurement of dissolved parameters (Nayar and Chou 2003;
Hulatt and Thomas 2010). A subset of these GF/F filtered samples for colored dissolved organic matter (CDOM) and fluorescent dissolved organic matter (FDOM) were stored in acid-washed $(10 \% \mathrm{HCl})$ and pre-combusted glass vials at $4{ }^{\circ} \mathrm{C}$ until absorbance and fluorescence measurements were made within two weeks from sampling. Stedmon et al. (2000) investigated the effects of storage on CDOM absorption and found little change for periods of up to $27 \mathrm{~d}$. Another filtered subset of samples for size-exclusion chromatography (SEC) measurement were stored in identical vials at $-20^{\circ} \mathrm{C}$ until analysis. DOC samples were acidified with $\mathrm{H}_{3} \mathrm{PO}_{4}$ and stored frozen at $-20^{\circ} \mathrm{C}$ until measurement.

\subsection{Analyses}

DOC concentrations were analyzed by high temperature combustion on an MQ1000 TOC analyzer according to Qian and Mopper (1996). Analysis integrity was tested daily on the certified reference material (University of Miami, Consensus Reference Materials, Florida Straight water, lot \#0510: $41-44 \mu \mathrm{mol} \mathrm{CL^{-1 }}$ ), the method yielded an average of $42 \pm 6.5$ (SD) $\mu \mathrm{mol} \mathrm{C} \mathrm{L}{ }^{-1}(n=213)$. The inorganic nutrient analyses were carried out according to Grasshoff et al. (1983) where the $\mathrm{NH}_{4}^{+}$analyses were always done manually and for the $\mathrm{NO}_{2}^{-}, \mathrm{NO}_{3}^{-}$, and $\mathrm{PO}_{4}^{3-}$ analyses an automated flow injection analyzer was used (Lachat QC 8000). TN and total dissolved nitrogen (TDN; from the filtered fraction) were determined following alkaline persulfate oxidation (Koroleff, 1977; Grasshoff et al., 1999) followed by automated analysis. DON was calculated by subtracting the combined inorganic nitrogen from the TDN.

Spectrophotometric analyses of CDOM samples were performed using a PerkinElmer Lambda 650 UV/VIS spectrophotometer with $1 \mathrm{~cm}$ quartz cuvette over the spectral range from 200 to $800 \mathrm{~nm}$ with $1 \mathrm{~nm}$ intervals. Milli-Q 
(Millipore) water was used as the reference for all samples. Absorbance measurements were transformed to absorption coefficients by multiplying by 2.303 and dividing by the path length $(0.01 \mathrm{~m})$. The absorption spectra were characterized by fitting an exponential model with a nonlinear regression as described in Stedmon et al., (2000). A slope of these spectra, S coefficient for wavelengths $275-295 \mathrm{~nm}\left(\mathrm{~S}_{275-295}\right)$ were calculated. These values were used to give an indication of the qualitative properties of CDOM, instead of just quantitative (such as CDOM absorption at a certain wavelength) in the samples (Asmala et al., 2012). SUVA 254 is defined as the UV absorbance at 254 nanometers measured in inverse meters $\left(\mathrm{m}^{-1}\right)$ divided by the DOC concentration measured in milligrams per liter (Weishaar et al., 2003).

Excitation-emission matrices of fluorescence were measured for DOM samples in $1 \mathrm{~cm}$ quartz cuvette in a Varian Cary Eclipse fluorometer (Agilent). Bandwidths were set to $5 \mathrm{~nm}$ for excitation and $4 \mathrm{~nm}$ for emission. A series of emission scans (280-600 nm) were collected over excitation wavelengths ranging from 220 to $450 \mathrm{~nm}$ in $5 \mathrm{~nm}$ increments. Fluorescence spectra were corrected for inner filter effects, which accounted for the absorption of both excitation and emission light by the sample in the cuvette (Mobed et al., 1996). This was done following the methods of McKnight et al. (2001). The FDOM spectra (excitation and emission) were also corrected for instrument biases using an excitation correction spectrum derived from a concentrated solution of oxazine 1 and an emission correction spectrum derived using a ground quartz diffuser. Fluorescence spectra were Raman calibrated by normalizing to the area under the Raman scatter peak (excitation wavelength of $350 \mathrm{~nm}$ ) of a Milli$\mathrm{Q}$ water sample, run on the same session as the samples. To remove the Raman signal, a Raman normalized Milli-Q excitation-emission matrix (EEM) was subtracted from the sample data. As the measured signal was normalized to the Raman peak and excitation and emission correction spectra were used, all the instrument specific biases were effectively removed. Rayleigh scatter effects were removed from the data set by not including any emission measurements made at wavelengths $\leq$ excitation wavelength $+20 \mathrm{~nm}$. Fluorescence peaks $\mathrm{C}, \mathrm{A}, \mathrm{M}$ and $\mathrm{T}$ were extracted from the EEM data (Coble, 1996). Peak A is a primary fluorescence peak from dissolved humic substances; peak $\mathrm{C}$ is a secondary humic substance peak characteristic of terrestrially derived DOM; peak $\mathrm{M}$ is a secondary humic substance peak characteristic of marine-derived DOM; peak T is a peak attributable to fluorescence from the aromatic amino acid tryptophan (Coble, 1996).

Bacterial abundance was determined by flow cytometry after Gasol et al., (1999) and Gasol and del Giorgio (2000). Samples were analyzed with an LSR II flow cytometer (BD Biosciences) using a $488 \mathrm{~nm}$ laser. Cells were stained with SYBR Green I (Molecular Probes) at a final concentration of $1: 10000$ for at least $10 \mathrm{~min}$ in the dark and analyzed within $30 \mathrm{~min}$ of staining. CountBright beads
(Molecular Probes) were added to each sample to calculate the volume of sample. Bacterial data were acquired for $1 \mathrm{~min}$, and cell populations identified from bivariate plots of green fluorescence (fluorescein isothiocyanate, FITC) vs. side scatter (SSC). Gating analysis was performed using FACS Diva software (BD Biosciences). Total bacterial abundance in cells $\mathrm{mL}^{-1}$ were calculated from sample flow rates inferred from sample volumes obtained and number of events recorded. Each experimental set of samples was analyzed during one measurement session.

Bacterial production was measured using both the ${ }^{3} \mathrm{H}$ thymidine (Fuhrman and Azam, 1980, 1982) and ${ }^{14} \mathrm{C}$-leucine (Kirchman et al., 1989) incorporation techniques. Dual labeling of $10 \mathrm{~mL}$ duplicate samples and an adsorption control was done with [methyl ${ }^{3} \mathrm{H}$ ] thymidine (final concentration $20 \mathrm{nmol} \mathrm{L}^{-1}$ ) and L-[U- $\left.{ }^{14} \mathrm{C}\right]$ leucine (final concentration $160 \mathrm{nmol} \mathrm{L}^{-1}$ ). The samples were incubated for $2-3 \mathrm{~h}$ at the same temperature as the experimental units. The incubations were terminated by the addition of formaldehyde, and the samples were refrigerated until further processing. Within $48 \mathrm{~h}$ the samples were extracted with cold trichloroacetic acid (TCA, $5 \%$ final concentration) and filtered onto $0.2 \mu \mathrm{m}$ mixed cellulose ester filters (Advantec MFS, Inc.) in icecold conditions. The amount of radioactivity on the filters was measured using a Wallac WinSpectral 1414 Scintillation counter (PerkinElmer) and InstaGel scintillation cocktail (PerkinElmer).

Dissolved oxygen (DO) was measured using a Winkler titration conducted by dynamic endpoint titration with a Metrohm 848 Titrino Plus potentiometric titrator (Metrohm $\mathrm{AG})$. The dissolved oxygen consumption $\left(\mathrm{mg} \mathrm{OL}^{-1} \mathrm{~h}^{-1}\right)$ was converted to carbon respiration ( $\mathrm{mg} \mathrm{C} \mathrm{L}^{-1} \mathrm{~h}^{-1}$ ) assuming a respiratory quotient (RQ) of 1 .

BGE was calculated by dividing bacterial production (BP) with bacterial carbon demand (BCD), which is the sum of bacterial production and bacterial respiration (BR): $\mathrm{BGE}=$ $\mathrm{BP} /(\mathrm{BCD})$. Bacterial production was determined in three ways: (1) converting bacterial cell numbers from flow cytometry to carbon, (2) leucine incorporation to carbon and (3) thymidine incorporation to carbon. Cell numbers were converted to carbon units with a conversion factor value of $30.2 \mathrm{fg} \mathrm{C}$ cell $^{-1}$ (Fukuda et al., 1998). Leucine incorporation was converted to carbon units using the value of $1.5 \mathrm{~kg}$ $\mathrm{C} \mathrm{mol}^{-1}$ incorporated (Simon and Azam, 1989; Kirchman et al., 1989). Thymidine incorporation was converted to carbon units using the conversion factor of $1.10 \times 10^{18} \mathrm{cells} \mathrm{mol}^{-1}$ (Riemann et al., 1987) and carbon content of $30.2 \mathrm{fg} \mathrm{C}$ cell $^{-1}$ (Fukuda et al., 1998). The cell to carbon conversion factor used for BGE estimates $\left(30.2 \mathrm{fg} \mathrm{C}\right.$ cell $^{-1}$, Fukuda et al., 1998 ) is within the range of other cell to carbon values used in the Baltic Sea region (20-35 $\mathrm{fg} \mathrm{C}$ cell $^{-1}$, Lee and Fuhrman 1987; Fagerbakke et al., 1996; Søndergaard and Middleboe, 1995). To address the built-in uncertainty of the cell to carbon conversion factors, we used a range of cell carbon values presented by Fukuda et al. (1998) when calculating carbon 
fluxes from natural systems. This range of $\pm 12.3 \mathrm{fg} \mathrm{C}$ cell $^{-1}$ includes these other commonly used conversion factors, and illustrates the effect of varying conversion factors to the final loading values. We used a time-weighted average of leucine and thymidine incorporation rates during the experiment for BGE calculations. BR was calculated from oxygen consumption during the experiment. For further analysis, we averaged the results of three BGE methods $\left({ }^{3} \mathrm{H}\right.$-thymidine, ${ }^{14} \mathrm{C}$ leucine and bacterial cell numbers) used.

We analyzed the molecular size of DOM with sizeexclusion chromatography (SEC). The SEC analyzer consisted of an integrated autosampler and pump module (GPCmax, Viscotek Corp.), a linear type column (TSK $\mathrm{G}^{2} 200 \mathrm{SW}_{\mathrm{XL}}$ column; $7.8 \times 300 \mathrm{~mm}, 5 \mu \mathrm{m}$ particle size, Tosoh Bioscience $\mathrm{GmbH}$ ), a guard column (Tosoh Bioscience $\mathrm{GmbH}$ ) and a UV detector (Waters 486 Tunable Absorbance Detector) set to $254 \mathrm{~nm}$. The flow rate was $0.8 \mathrm{~mL} \mathrm{~min}^{-1}$ and the injection volume $100 \mu \mathrm{L}$. The columns were thermo-regulated in a column oven (Croco-cil 100040-220P, Cluzeau Info Labo) at $25^{\circ} \mathrm{C}$. The data were collected with OmniSEC 4.5 software (Viscotek Corp.). The eluent was $0.01 \mathrm{M}$ acetate buffer at a pH of 7.00 (Vartiainen et al., 1987). Prior to injection, the samples were filtered through a $0.2 \mu \mathrm{m}$ PTFE syringe filter. The system was calibrated using a combination of standards, as follows: acetone, ethylene glycol, salicylic acid, polystyrene sulfonate (PSS) $3.5 \mathrm{kDa}$ and PSS $6.5 \mathrm{kDa}(58,100,138,3610$, and $6530 \mathrm{Da}$, respectively). The calibration curve was linear $\left(R^{2}=0.99\right)$ over the apparent molecular weight (AMW) range tested. Comparison between SEC method and absorbance measurements $\left(a_{(\mathrm{CDOM} 254)}\right)$ yielded a linear correlation coefficient of 0.92 , indicating high qualitative recovery of DOM with the SEC method, as measured from the integrated signal of the SEC chromatogram. From the integrated signal we calculated weighted and number averaged apparent molecular weights $\left(\mathrm{AMW}_{\mathrm{w}}\right.$ and $\mathrm{AMW}_{\mathrm{n}}$, respectively) and molecular dispersity $\left(\mathrm{AMW}_{\mathrm{n}}: \mathrm{AMW}_{\mathrm{w}}\right)$.

For studying the statistically significant differences between the experimental units, we performed analyses of variance (single factor ANOVA), analysis of covariance, Welch's $t$ test and for post-hoc analysis we used Tukey's HSD. All statistical analyses were done using the basic functions of $\mathrm{R}$ software (R Core Team, 2012).

\section{Results}

\subsection{Initial DOM characteristics across seasons and sites}

There were significant differences in the starting DOM quantity and quality between both estuaries and seasons (Table 2). In Table 2 the data from the initial conditions is divided between the river and sea endmembers to assess the difference between the "source" and the "sink" of DOM in the coastal areas, which essentially is the efficiency of the so-called coastal filter (Lisitsyn, 1995). The experimental treatments (salt and nutrient additions and the combination of those) did not have an effect on the DOM characteristics at the start (data not shown).

In the river samples, DOC concentrations were high in forested Kiiminkijoki and agricultural Kyrönjoki, and bulk DOM had aromatic, humic-like properties, revealed by high $\mathrm{SUVA}_{254}$ and fluorescence peak $\mathrm{C}$ values. Of the fluorescence peaks measured (A, C, M and T), we chose to concentrate on peak $\mathrm{C}$, since the peak $\mathrm{C}$ is a proxy for humiclike, terrestrial substances in the DOM pool (Cammack et al., 2004; Stedmon and Markager, 2005). Also, since peaks $\mathrm{A}$ and $\mathrm{M}$ covaried significantly with peak $\mathrm{C}\left(R^{2}=0.98\right)$, we did not continue analyses of $\mathrm{A}$ and $\mathrm{M}$ peaks, as they contributed minor additional information. In addition, DON concentrations were substantially higher in Kyrönjoki. The Karjaanjoki river samples had half of the DOC concentration compared to the other two, and the bulk DOM had a less pronounced terrestrial signal, indicated by DOM quality parameters $\left(\mathrm{SUVA}_{254}\right.$, UV slope, humic-like fluorescence peak and molecular weight). There was also seasonal variability in some of the DOM variables in the river samples. In spring, DOC concentration and aromaticity was lowest. In the sea endmember, terrestrial signal was strongest in the Kiiminkijoki estuary, as indicated by the DOM quality parameters. DON concentration was significantly higher in the Karjaanjoki sea samples than in the other two estuaries. There were no seasonal trends in study variables in the sea samples.

\subsection{Bioavailability of DOM}

DOM degradation is expressed as the proportional difference between the start and the end value of each parameter in incubations and hereafter referred as the $\Delta(\%)$-value (Table 2). There were significant differences between the estuaries in the $\Delta(\%)$-value of all variables except the molecular weight of the DOM. There was no seasonal difference in the $\Delta(\%)-$ values of DOC and DON, but there were differences in DOM quality (CDOM slope and fluorescent DOM character). The water type (river water, $1: 1 \mathrm{mix}$, seawater) made no difference to the $\Delta(\%)$-values. Experimental treatments (nutrient and salt addition and the combination of those) did not have significant differences in $\Delta(\%)$-values of any study variables (data not shown). Contrary to the expected, seasonal variability turned out to be minor (and less significant) compared to the differences observed between estuaries for $\Delta(\%)$-values for the majority of variables. Since the specific estuary was found to be the key determinant of $\Delta(\%)$-values of many study parameters, in the following we mainly focus on the differences between estuaries in this article.

The portion of DOC and DON that was bioavailable (BDOC and BDON) did not significantly differ between estuaries (Table 3). The relative size (\%) of BDOC and the daily consumption rates varied significantly between the estuaries, being lowest in the forest and peatland-dominated 
Table 2. Initial conditions and cumulative changes $(\Delta)$ of DOM parameters during the $12-18 \mathrm{~d}$ dark incubations: average DOC and DON concentrations, DOC-specific UV absorbance at $254 \mathrm{~nm}\left(\mathrm{SUVA}_{254}\right)$, average slope coefficient between 275 and $295 \mathrm{~nm}$, fluorescence intensity of peak C and weighted averages of apparent molecular weight. Whole data is divided by study estuaries and seasons. "Estuary" includes all seasons, "Season" includes all estuaries. KA: Karjaanjoki, KI: Kiiminkijoki and KY: Kyrönjoki. Significance level of differences between groups (Sig.) as analyzed by ANOVA is also given: $*-<0.05, * *<0.01, * * *<0.001$, n.s.: not significant. Quantitative variables are in bold, as qualitative variables are not.

\begin{tabular}{|c|c|c|c|c|c|c|c|c|}
\hline \multicolumn{9}{|c|}{ Initial conditions - river endmember } \\
\hline & \multicolumn{4}{|c|}{ Estuary } & \multicolumn{4}{|c|}{ Season } \\
\hline & KA & KI & KY & Sig. & Spring & Summer & Autumn & Sig. \\
\hline DOC $\left(\mu \mathrm{mol} \mathrm{L} \mathbf{L}^{-1}\right)$ & $585 \pm 51$ & $1113 \pm 230$ & $1283 \pm 272$ & $* * *$ & $880 \pm 219$ & $1021 \pm 372$ & $1192 \pm 501$ & $*$ \\
\hline $\operatorname{DON}\left(\boldsymbol{\mu m o l} \mathbf{L}^{-1}\right)$ & $27.3 \pm 3.4$ & $29.4 \pm 4.4$ & $100.2 \pm 71.5$ & $* * *$ & $67.5 \pm 67.7$ & $33.0 \pm 5.5$ & $30.8 \pm 4.0$ & n.s. \\
\hline $\operatorname{SUVA}_{254}\left(\mathrm{mg} \mathrm{L}^{-1} \mathrm{~m}^{-1}\right)$ & $3.58 \pm 0.33$ & $5.41 \pm 0.40$ & $4.51 \pm 0.85$ & $* * *$ & $4.31 \pm 0.90$ & $5.76 \pm 0.47$ & $4.91 \pm 0.16$ & $* * *$ \\
\hline $\mathrm{S}_{275-295}\left(\mu \mathrm{m}^{-1}\right)$ & $16.6 \pm 0.2$ & $11.9 \pm 0.2$ & $13.5 \pm 1.2$ & $* * *$ & $14.1 \pm 2.0$ & $12.0 \pm 0.2$ & $12.4 \pm 0.5$ & $* *$ \\
\hline Peak C (R.U.) & $0.78 \pm 0.12$ & $1.69 \pm 0.21$ & $2.17 \pm 0.34$ & $* * *$ & $1.49 \pm 0.49$ & $1.65 \pm 0.70$ & $1.71 \pm 0.78$ & n.s. \\
\hline $\mathrm{AMW}_{\mathrm{W}}(\mathrm{Da})$ & $2374 \pm 253$ & $2875 \pm 239$ & $2609 \pm 274$ & $* * *$ & $2657 \pm 292$ & $2484 \pm 254$ & $2672 \pm 435$ & n.s. \\
\hline \multicolumn{9}{|c|}{ Initial conditions - sea endmember } \\
\hline & \multicolumn{4}{|c|}{ Estuary } & \multicolumn{4}{|c|}{ Season } \\
\hline & KA & KI & KY & Sig. & Spring & Summer & Autumn & Sig. \\
\hline DOC $\left(\mu \mathrm{mol} \mathrm{L} \mathrm{L}^{-1}\right)$ & $363 \pm 37$ & $393 \pm 27$ & $417 \pm 67$ & n.s. & $414 \pm 54$ & $372 \pm 17$ & $363 \pm 46$ & n.s. \\
\hline $\operatorname{DON}\left(\boldsymbol{\mu m o l} \mathbf{L}^{-1}\right)$ & $19.3 \pm 1.7$ & $15.0 \pm 0.5$ & $12.9 \pm 3.5$ & $* * *$ & $15.2 \pm 4.0$ & $16.3 \pm 2.4$ & $18.1 \pm 3.5$ & n.s. \\
\hline $\operatorname{SUVA}_{254}\left(\mathrm{mg} \mathrm{L}^{-1} \mathrm{~m}^{-1}\right)$ & $1.87 \pm 0.09$ & $3.47 \pm 0.27$ & $2.35 \pm 0.18$ & $* * *$ & $2.61 \pm 0.85$ & $2.42 \pm 1.0$ & $2.82 \pm 0.56$ & n.s. \\
\hline$S_{275-295}\left(\mu \mathrm{m}^{-1}\right)$ & $24.4 \pm 0.2$ & $17.3 \pm 1.5$ & $20.5 \pm 2.1$ & $* *$ & $19.5 \pm 3.9$ & $22.2 \pm 2.0$ & $20.2 \pm 2.0$ & n.s. \\
\hline Peak C (R.U.) & $0.22 \pm 0.10$ & $0.43 \pm 0.06$ & $0.30 \pm 0.08$ & $* *$ & $0.36 \pm 0.14$ & $0.26 \pm 0.08$ & $0.33 \pm 0.11$ & n.s. \\
\hline $\mathrm{AMW}_{\mathrm{w}}(\mathrm{Da})$ & $2000 \pm 31$ & $2393 \pm 182$ & $2192 \pm 137$ & $* * *$ & $2256 \pm 224$ & $2055 \pm 79$ & $2166 \pm 252$ & n.s. \\
\hline \multicolumn{9}{|c|}{$\Delta(\%)-$ all experiment units pooled } \\
\hline & \multicolumn{4}{|c|}{ Estuary } & \multicolumn{4}{|c|}{ Season } \\
\hline & KA & KI & KY & Sig. & Spring & Summer & Autumn & Sig. \\
\hline DOC & -10.6 & -7.91 & -9.34 & $*$ & -7.99 & -9.72 & -2.79 & n.s. \\
\hline DON & -10.0 & -5.46 & -21.9 & $* * *$ & -13.15 & -2.08 & 1.96 & n.s. \\
\hline SUVA $_{254}$ & 17.1 & 5.8 & 11.1 & $* *$ & 12.1 & 9.3 & 6.0 & n.s. \\
\hline$S_{275-295}$ & -2.55 & -0.03 & -0.47 & $* * *$ & -1.08 & 1.27 & -1.26 & $* * *$ \\
\hline Peak C & 13.0 & -2.58 & -1.02 & $*$ & -2.36 & 7.61 & 5.77 & * \\
\hline $\mathrm{AMW}_{\mathrm{W}}$ & 1.85 & 0.60 & 0.27 & n.s. & 0.77 & 1.61 & 0.14 & n.s. \\
\hline
\end{tabular}

Kiiminkijoki estuary and highest in the agricultural Kyrönjoki estuary. BDON, \%BDON and DON degradation rates were all significantly different among estuaries, being lowest in Kiiminkijoki and highest in Kyrönjoki. Furthermore, the ratio with which DOC and DON were consumed varied significantly among estuaries, being three times higher in Kiiminkijoki than in Kyrönjoki.

\subsection{Effects of land use on DOM degradation}

\subsubsection{DOC and DON concentrations}

The three study estuaries have clearly different land use (Table 1), and differences in bioavailability of DOC and DON reflected this (Fig. 3). The Kiiminkijoki estuary catchment is largely dominated by natural forests and peatlands and had the lowest biodegradable fraction and degradation rates. Kyrönjoki, which is heavily influenced by agriculture, had the highest proportion of BDON, and also the highest DOC and DON degradation rates. Considering the different landcover types, three classes were found to covary with the changes in BDOC and BDON: combined forests and peatlands, lakes and agriculture. A higher percentage of forests and peatlands in the catchment decreased the bioavailability of DOC. Longer retention time in the catchment, as indicated by lake percentage, decreased DON bioavailability, whereas higher agricultural land use increased DON bioavailability.

The DOC: DON ratios varied substantially between estuaries, ranging on average from 21 in Karjaanjoki to 40 in Kyrönjoki (Fig. 4a). In the Karjaanjoki and Kiiminkijoki estuaries the variation in DOC: DON ratios was small, but in 


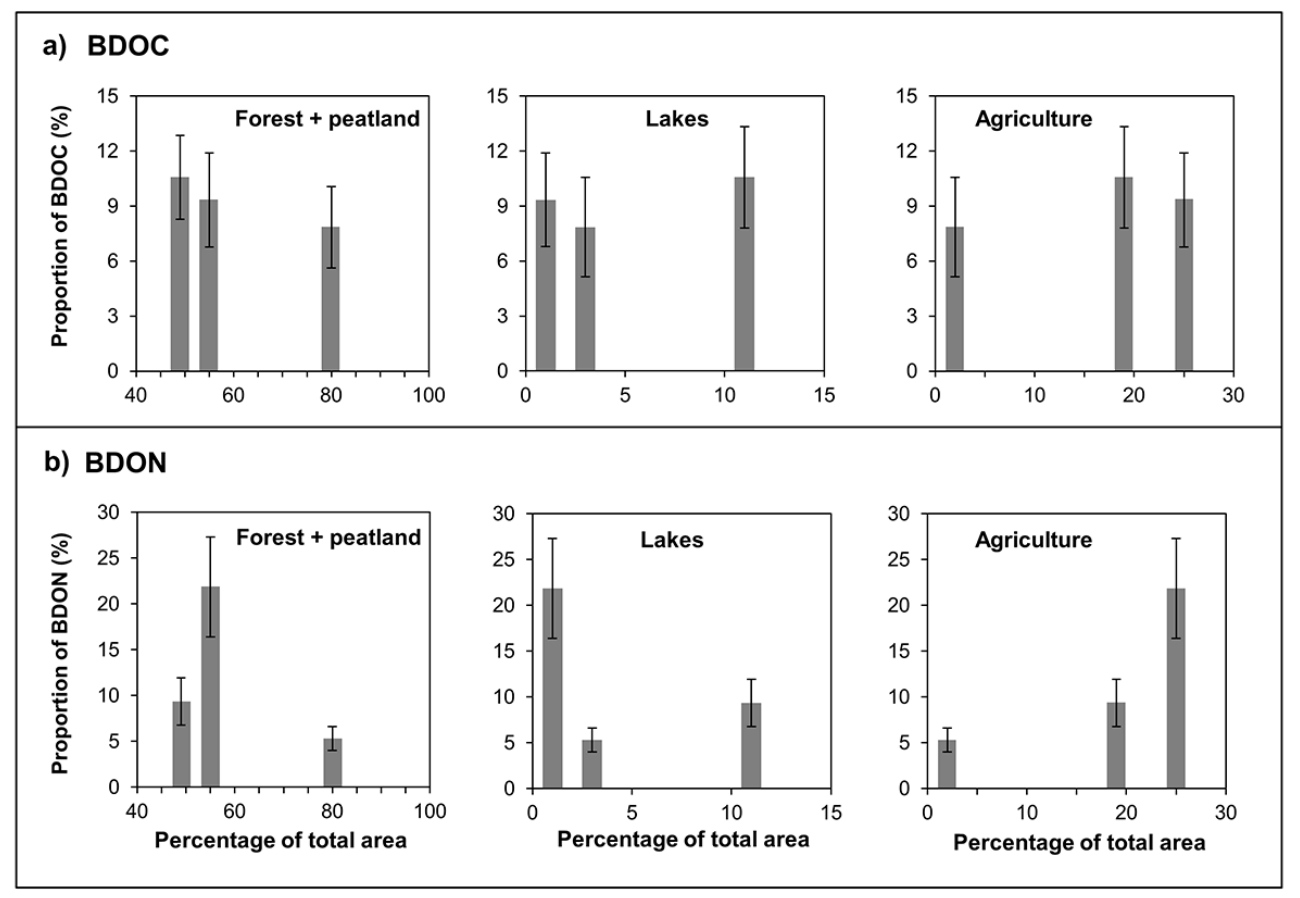

Fig. 3. Relationships between proportional land use categories and biodegradable fractions of DOC and DON of the whole pool (panels a and $\mathbf{b}$, respectively). The proportion of different land use categories is presented as percentage of total catchment area on $x$ axis and the biodegradable proportion of DOC and DON is on the $y$ axis.

agricultural Kyrönjoki the variation was considerable (from 4 to 243). This variation was mainly caused by the spring samples, where the lowest DOC: DON values were measured. In the other two estuaries this spring effect was not detected.

The ratio of biodegradable DOC (BDOC) and biodegradable DON (BDON) also varied between the estuaries, being 12 in Kyrönjoki, 19 in Karjaanjoki and 52 in Kiiminkijoki (Fig. 4b). In Karjaanjoki and Kiiminkijoki degradation ratios of BDOC:BDON followed the original DOC:DON ratio, but in Kyrönjoki average degradation ratio was significantly lower than the DOC:DON concentration ratio (12 and 38, respectively).

\subsubsection{DOM quality indicators}

Besides the quantitative changes (as indicated by DOC and DON concentrations), there were also changes in DOM quality. We measured significant changes in CDOM and fluorescent DOM properties, but not in molecular weight during the experiments. There were significant differences between estuaries on the $\Delta(\%)$-values in CDOM in experimental units: DOM aromaticity indicator $\mathrm{SUVA}_{254}$ was highest in Karjaanjoki and lowest in Kiiminkijoki (Fig. 5) in all experimental treatments. $\mathrm{SUVA}_{254}$ increased and the UV slope of CDOM $\left(S_{275-295}\right)$ decreased in waters from all three estuaries and seasons during the experiment, except in the summer units where the slope increased. The $\Delta(\%)$-values of peak C decreased in Kiiminkijoki and Kyrönjoki experimental units, and increased in Karjaanjoki experimental units. Similarly to UV slope, there was an increase in summer units, and also in autumn units in $\Delta(\%)$-values of humic-like peak $\mathrm{C}$.

Molecular weight parameters did not change significantly during the incubations, and there were no significant differences in $\Delta(\%)$-values between estuaries $(P>0.05)$. However, for the whole data set there were minor average changes in weight-averaged apparent molecular weight $\left(\mathrm{AMW}_{\mathrm{W}}\right)$, from $2466 \mathrm{Da}$ in the beginning to $2444 \mathrm{Da}$ in the end. The slope $S_{275-295}$ proved to be a good proxy for the $\mathrm{AMW}_{\mathrm{w}}$ in all of the experimental units (Fig. 6). Previously, Helms et al. (2008) had related this slope to the molecular weight of DOM, and recently use of this slope has been expanded to trace terrigenous DOC (Fichot and Benner, 2012).

There were significant differences in bacterial growth efficiency among experiment variables, estuary, water type (endmember) and treatment (nutrient addition). Seasonal variation between experimental units was not significant $(P>0.05)$. We measured an average BGE of 0.33 , ranging from 0.25 to 0.41 (Fig. 7), which is within the typical range for estuarine data sets (del Giorgio and Cole, 1998). The forested Kiiminkijoki estuary had the lowest BGE, followed by the agricultural Kyrönjoki, and the Karjaanjoki estuary had the highest BGE. The river samples had lower BGE than the sea samples, and nutrient addition increased the BGE.

When pooling the whole data set, we measured multiple significant $\left(P<0.001, R^{2}=0.18-0.27\right)$ overall 

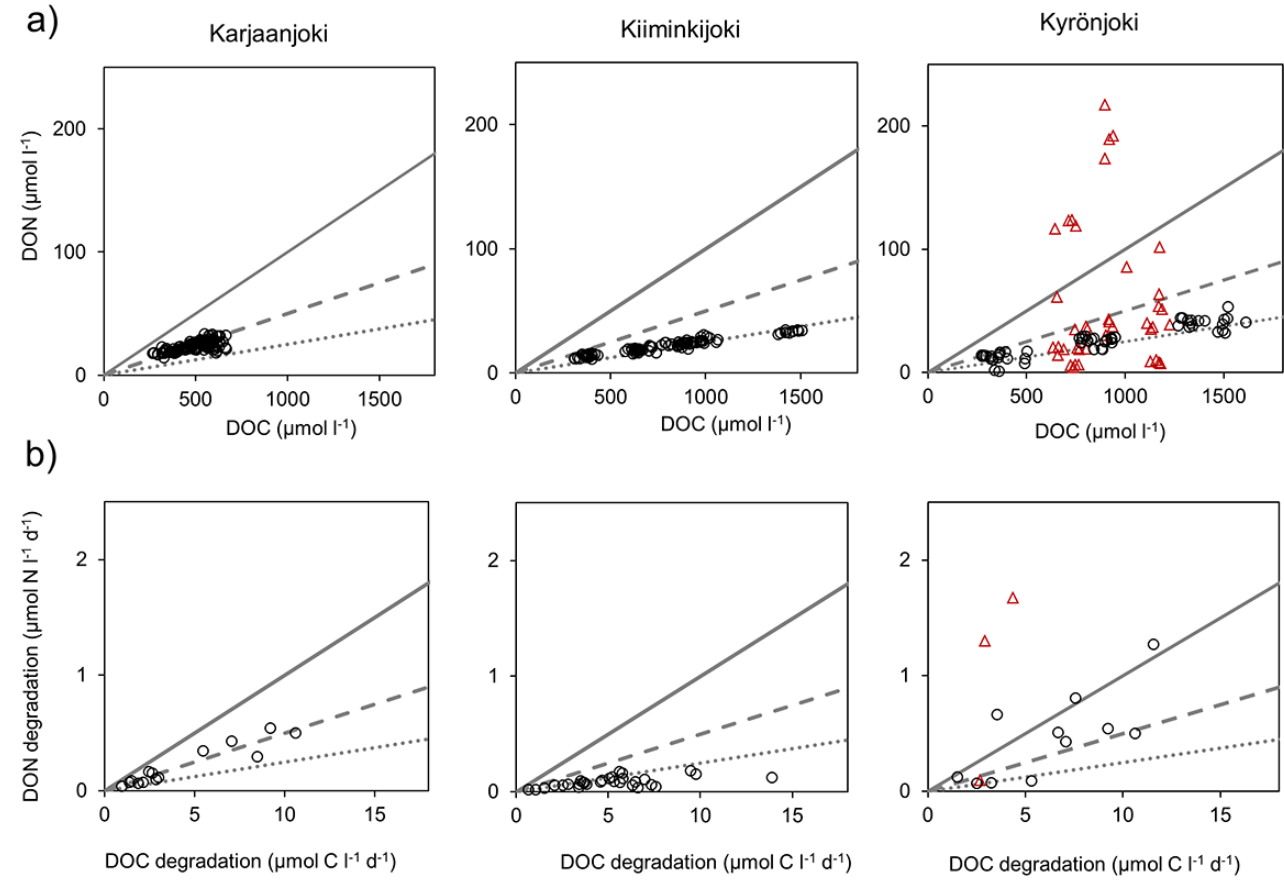

Fig. 4. Relationships between (a) DOC and DON concentrations in experiment units, and (b) daily degradation rate of DOC and DON in study estuaries. Lines denote fixed C : N relationships: solid line $=10$, dashed line $=20$ and dotted line $=40$. In the Kyrönjoki graph $(\mathbf{a})$, the spring values are separated from other seasons as most of them deviate significantly from the average DOC: DON ratio of 40 measured in other seasons in Kyrönjoki. This spring subset is differentiated from the other data with red triangles. For each (a) figure, whole experiment data was used, and for each (b) figure, only differences between start and end were used.

relationships between BGE and a selection of independently measured DOM quantity and quality parameters (Fig. 8). These relationships did not vary significantly between estuaries $(P>0.05)$. AMW ${ }_{\mathrm{w}}$ had the highest coefficient of determination $\left(R^{2}\right), 0.27$. BGE decreased with increasing molecular size over the molecular range of 1860-3320 Da. Increase in slope coefficient between 275 and $295 \mathrm{~nm}$ resulted as an increase in BGE $\left(R^{2}=0.23\right)$. DOC-specific UV absorbance $\left(\mathrm{SUVA}_{254}\right)$ was inversely related to BGE $\left(R^{2}=0.19\right)$, as well as the humic-like fluorescence peak $\mathrm{C}\left(R^{2}=0.18\right)$. DOC and DON concentrations influenced BGE less significantly compared with these quality variables.

Although statistically significant, most of regression analyses resulted in with coefficients of determination $\left(R^{2}\right.$ values) well below the critical threshold of 0.65 (Prairie, 1996). This limits the predictive power of our results, but does not prevent the use of the data to describe the complex interdependencies of DOC and DON concentrations, DOM quality and BGE.

\section{Discussion}

\subsection{DOC and DON degradation}

The only experimental variable significantly affecting DOC and DON degradation was the estuary, i.e., the source. This means that the initial qualities of DOC and DON (as specified in Table 2), determined by the catchment characteristics, were the major factor defining the biodegradability of DOC and DON, which supports our main hypothesis. Bioavailability of DOM has been previously reported to have strong seasonal variation (Lønborg et al., 2009; Sintes et al., 2010). However, in the experiments presented here the season surprisingly did not have significant effect on DOC and DON degradation in spite of the seasonal changes in DOM quantity and quality in study estuaries (Fig. 5). This implies that seasonal variation in DOM quality was balanced by seasonally adapted performance of the bacterial communities resulting as steady total utilization of DOC and DON. The water type (river, sea, 1:1 mix) did not affect DOC and DON degradation rates, indicating that the degradable portions of DOC and DON in the river waters were still available in the saline water or the microbial communities in the saline waters were more adapted to use different DOM sources than the river communities (Bouvier and del Giorgio, 2002). 

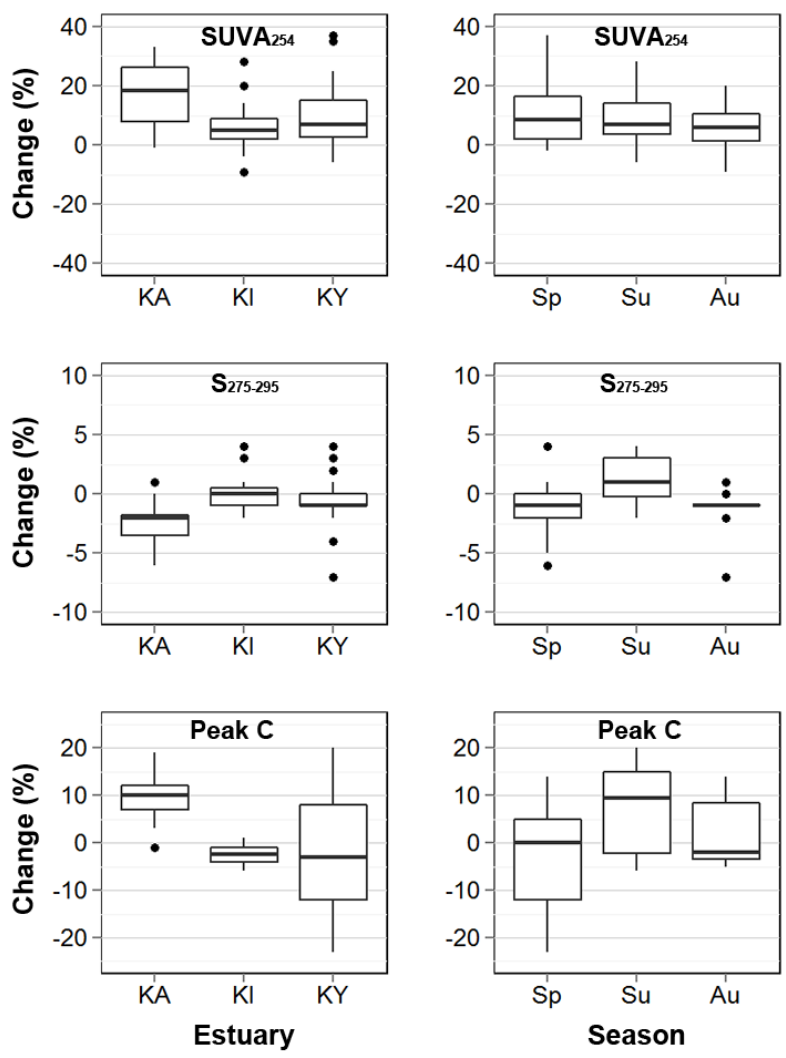

Fig. 5. Box plots showing $\Delta(\%)$-values of $\mathrm{SUVA}_{254}$, slope coefficient $S_{275-295}$ and fluorescent peak C variables during the degradation experiment. Whiskers indicate the minimum and maximum observations, lower and upper ends of boxes indicate lower and upper quartiles, and thick horizontal line is the mean value of the data set. Circles denote outliers in the data. Positive values indicate an increase of the variable during the experiment, negative value means loss. On the left side is change between estuaries and on the right side change between seasons. KA: Karjaanjoki, KI: Kiiminkijoki and KY: Kyrönjoki. Au: autumn, Sp: spring and $\mathrm{Su}$ : summer.

We also investigated the influence of inorganic nutrient limitation, and the effects of changes in salinity conditions. The insignificant effect of inorganic nutrient addition on biodegradable DOC and DON amounts suggests that the DOM degradation in the experiments was not limited by inorganic nitrogen or phosphorus availability. This is in contrast to a commonly observed stimulation of heterotrophic DOC utilization by addition of inorganic nutrients (e.g., Kuparinen and Heinänen, 1993; Zweifel et al., 1995). Neither did the addition of salt result in any significant changes in any of the study parameters. We hypothesize that this is the result of the major differences in DOM quality between the estuaries, masking the minor changes caused by the variations of salt tolerances between the bacterial communities. Also, salt-induced changes to DOM bioavailability do not occur when moving from fresh water to low-salinity estuarine conditions (Søndergaard et al., 2003). Furthermore, the

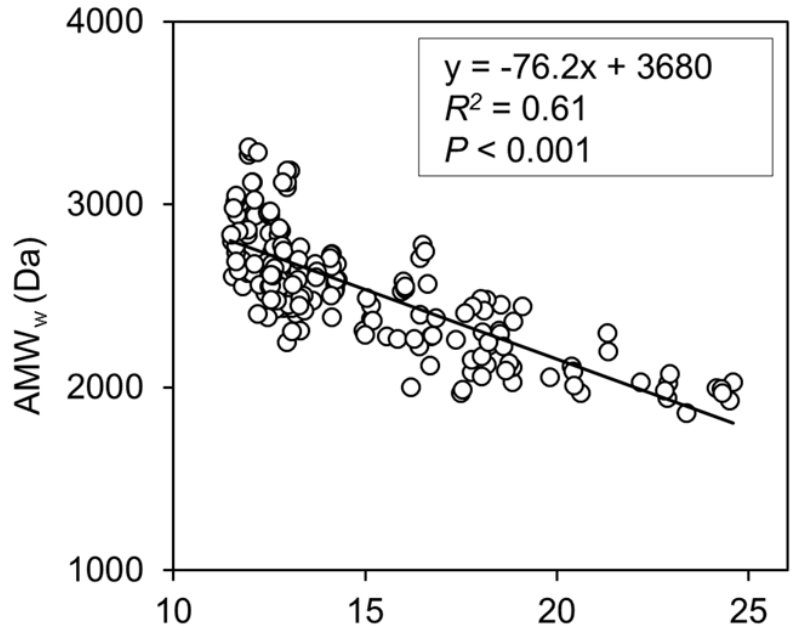

Fig. 6. Regression of AMW ${ }_{\mathrm{W}}$ versus slope coefficient $S_{275-295}$ of pooled experiment data $(n=135)$.

amount of salt needed in this study to reach the Baltic Sea values is considerably smaller than in transects having a fullstrength seawater endmember where significant alterations of humic substances have been reported (Kisand et al., 2013).

\subsection{Effects of land use to DOC and DON degradation}

The size of the biodegradable DOC pool was not significantly different between the estuaries $\left(56-79 \mu \mathrm{mol} \mathrm{L}^{-1}\right)$, but variation in the total DOC pool size led to significant proportional differences (\%BDOC and \%BDON; Table 3) between the estuaries. The amount of forests and peatlands in the catchment decreased the bioavailability of DOC in the estuary (Fig. 3), which concurs with previous findings comparing DOC bioavailability between forests and agricultural lands (Boyer and Groffman, 1996). The initial DOM in the Kiiminkijoki estuary expressed multiple indicators of refractory, humic-like quality: high $\mathrm{SUVA}_{254}$, high humic-like fluorescence and high molecular weight (Amon and Benner, 1996; Berggren et al., 2009). These same variables were all lower in Karjaanjoki, which also had the highest \%BDOC. The initial DOC concentrations in this estuary were 40-50\% lower than in the other two estuaries. Kiiminkijoki, with the forest and peatland-dominated catchment, had the lowest $\%$ BDOC. Overall, the differences in \%BDOC between estuaries were moderate, regardless of the significant differences in the land use of these estuaries.

The BDON pool was proportionally greates in the agricultural Kyrönjoki estuary, and lowest in Kiiminkijoki. The range in BDON was considerably larger than for BDOC, and BDON increased with agricultural land coverage in the catchment (Fig. 3). There was no similar relationship for BDOC and this is likely to be the result of continuous addition of inorganic nitrogen fertilizers to agricultural areas, which increase the (B)DON leaching from the soils, but not 
Table 3. Average amounts and standard deviations of biologically degradable DOC (BDOC) and DON (BDON), their proportion of the total DOC on DON pool, the degradation rates during the experiments and the DOC:DON ratios of degraded DOM. Since experiment durations varied (from 12 to $18 \mathrm{~d}$ ), BDOC and BDON amounts are normalized to $14 \mathrm{~d}$ (BDOC 14 and BDON 14 , respectively). Average values of each estuary include every season and every water type. The Karjaanjoki catchment has mixed land use with most urban areas of the three catchments, the Kiiminkijoki catchment is dominated ( $80 \%$ of total area) by mostly natural forests and peatlands, and the Kyrönjoki catchment is most heavily influenced by agriculture ( $25 \%$ of total area). Significance level of differences between estuaries (Sig.) as analyzed by ANOVA is also given: $*<0.05, * * *<0.001$, n.s.: not significant.

\begin{tabular}{|c|c|c|c|c|c|}
\hline & Karjaanjoki & Kiiminkijoki & Kyrönjoki & Sig. & Mean \\
\hline $\mathrm{BDOC}_{14}\left(\mu \mathrm{mol} \mathrm{L}^{-1}\right)$ & $64.8 \pm 37.0$ & $60.0 \pm 38.1$ & $78.7 \pm 45.0$ & n.s. & $65.7 \pm 39.7$ \\
\hline $\operatorname{BDOC}(\%)$ & $10.6 \pm 5.55$ & $7.91 \pm 5.13$ & $9.34 \pm 5.08$ & $*$ & $8.88 \pm 5.24$ \\
\hline DOC degradation rate $\left(\mu \mathrm{mol} \mathrm{L}^{-1} \mathrm{~d}^{-1}\right)$ & $4.26 \pm 2.64$ & $4.09 \pm 2.72$ & $7.14 \pm 3.22$ & * & $5.32 \pm 2.84$ \\
\hline $\mathrm{BDON}_{14}(\mu \mathrm{mol} \mathrm{L}-1)$ & $3.07 \pm 1.69$ & $1.15 \pm 0.63$ & $8.18 \pm 7.26$ & $* * *$ & $3.32 \pm 4.63$ \\
\hline $\operatorname{BDON}(\%)$ & $10.0 \pm 5.17$ & $5.46 \pm 2.74$ & $21.9 \pm 11.1$ & $* * *$ & $10.5 \pm 9.19$ \\
\hline DON degradation rate $\left(\mu \mathrm{mol} \mathrm{d}{ }^{-1}\right)$ & $0.23 \pm 0.12$ & $0.08 \pm 0.04$ & $0.62 \pm 0.52$ & $* * *$ & $0.24 \pm 0.33$ \\
\hline DOC : DON degradation ratio & $24.1 \pm 13.5$ & $57.0 \pm 40.6$ & $19.4 \pm 16.3$ & $* * *$ & $40.2 \pm 35.7$ \\
\hline
\end{tabular}

DOC (McDowell et al., 2004). In the Kyrönjoki estuary, where there is the largest proportion of agricultural areas, BDON was highest. The differences between DON concentrations of river and sea samples were also greatest in the Kyrönjoki system, indicating that the high amounts of DON flowing from the river are utilized rapidly in the coastal zone. It is notable that the very low DOC:DON ratios of Kyrönjoki in Fig. 4a were all from spring, when high spring freshetassociated surface runoff over ploughed cropland soil can be expected to transport high amounts of nitrogen into the river.

The variations in the BDOC:BDON ratios followed the patterns of quantity and quality of DON in the estuaries: Kyrönjoki, the predominantly agricultural catchment, had the largest BDON and the highest DON degradation rate (Sun et al., 1997) whereas forest and peatland-dominated Kiiminkijoki had the lowest. The relationship between BDOC and BDON amounts was significant in Karjaanjoki and Kiiminkijoki, implying that in Kyrönjoki there is a more complex mix of bioavailable compounds with different $\mathrm{C}: \mathrm{N}$ ratios (Fig. 4b). The relatively constant DOC:DON ratios in the Kiiminkijoki catchment resulted in the tightest coupling between BDOC and BDON, suggesting a homogenous pool of bioavailable compounds in that system.

The proportions of lakes in the catchment area did not influence the DOC bioavailability, but decreased DON bioavailability, suggesting that DON is intensively transformed within waterways (Brookshire et al., 2005; Mattsson et al., 2005). The most bioavailable fractions are subjected to biological uptake already during the transport through inland waters before entering the estuary, which highlights the role of residence time of terrestrial DOM in lotic systems. Karjaanjoki, with the most lakes $(9 \%)$ in its catchment, had half the BDON of Kyrönjoki, which has only $1 \%$ of lakes in its catchment.

In the Kiiminkijoki experiments high BDOC: BDON ratios were measured, implying that the heterotrophs in that system were utilizing DOM of poor quality to meet their energy demand (cf. Hopkinson et al., 1997). This might be a result of the low concentrations of DON in that particular system. Similar N-poor recalcitrant DOM has been reported to accumulate in oceanic systems (Kähler and Koeve, 2001). Also the refractory nature of forest and peatlandderived DOM in the Kiiminkijoki system may have caused the high $\mathrm{C}: \mathrm{N}$ ratio, and both low BDOC and BDON degradation rates (Hulatt et al., submitted).

Typically, in pristine areas with low anthropogenic influence organic carbon explains $95 \%$ of organic nitrogen variation (Kortelainen et al., 2006), which is supported by our measurements from Kiiminkijoki, where DOC and DON concentrations were tightly coupled (Fig. 4). We found weak relationships between DOC concentration and the \%BDOC, and between DON concentrations and the \%BDON. From this we conclude that in our study estuaries, the DOM quantity (DOC and DON concentrations) does not determine its bioavailability.

\subsection{Changes in DOM quality during incubations}

SUVA $_{254}$ increased in all estuaries and seasons during incubations (Table 2, Fig. 5). This increase indicates either the selective utilization of the non-colored or less aromatic DOM by microbes or the production of UV-absorbing compounds by bacteria (Ortega-Retuerta et al., 2009). The aromatic compounds, mostly deriving from lignin degradation, are likely to be the most stable and dominant fraction of DOM absorbing at $254 \mathrm{~nm}$ (Kalbitz et al., 2003b). As degradation of these compounds is strongly dependent of sunlight (Hernes and Benner, 2003; Cory et al., 2013), transformations of these compounds to more readily degradable bioavailable compounds in our dark incubations was not likely. Therefore it follows that the aromatic compounds SUVA $_{254}$ being the proxy) in the experiment units remained relatively unaffected by bacterial activity compared to non-colored DOM, and in 

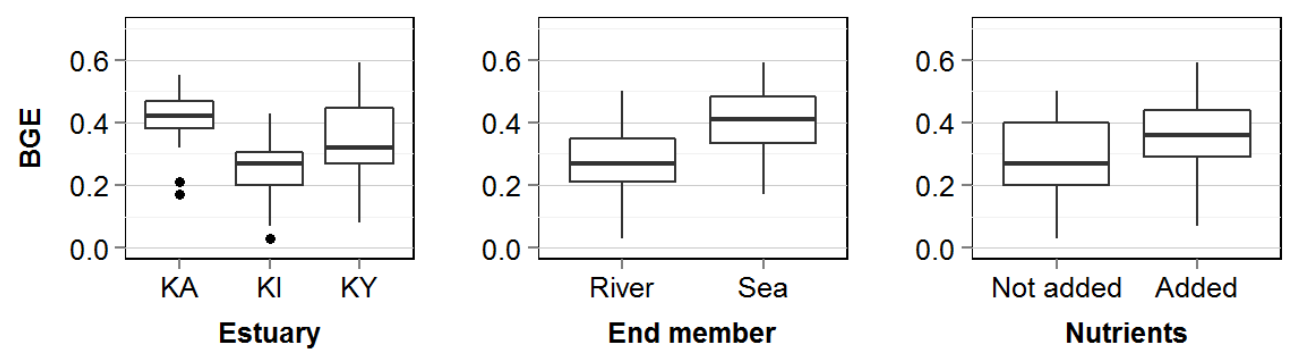

Fig. 7. Box plots showing variation in bacterial growth efficiencies between experiment units. Whiskers indicate the minimum and maximum observations, lower and upper ends of boxes indicate lower and upper quartiles, and thick horizontal line is the mean value of each data set. In the left panel data is divided by the estuaries: KA: Karjaanjoki, KI: Kiiminkijoki and KY: Kyrönjoki. In the middle panel the difference between river and sea endmembers is shown. In the right panel the effect of nutrient additions is presented. Differences between estuaries, endmembers and nutrient manipulations are significant $(P \leq 002)$.

addition newly created CDOM was added to the aromatic pool during the incubations (Nelson et al., 2004).

The UV slope $S_{275-295}$ decreased in the experiment units from every estuary, which indicates either a production of material absorbing at higher wavelengths or removal of compounds that absorb at lower wavelengths. However, in summer the UV slope increased. In summer the initial, riverine SUVA $_{254}$ was the highest, which may indicate higher plantderived DOM loading or that the DOM at the river mouth is further in its diagenetic continuum, i.e., processed more by the heterotrophic bacteria in the warm summer temperatures during transport along the hydrological path (Berggren et al., 2009). Additionally, it can be argued that in summer, the present bacterial community may be favoring utilization of non-aromatic, autochthonous DOM compared to aromatic, allochthonous DOM. All in all, the result was that CDOM was not altered evenly throughout the spectral range.

The fluorescent DOM peak $\mathrm{C}$ represents the humic-like fluorescent component of the DOM. Increases in the humic fluorescence can be expected if microbial humification processes dominated, with bacteria selectively degrading the bioavailable DOM and in the process generating humic fluorescence (Guillemette and del Giorgio, 2012; Shimotori et al., 2012). In the Karjaanjoki experimental units, the humic-like peak $\mathrm{C}$ increased significantly while in the humic-rich estuaries, Kiiminkijoki and Kyrönjoki, peak C was consumed. This is evidence that the bacterial communities in these systems are adapted to degrading humic material since it is abundantly available, even though it is not the most favorable substrate for heterotrophic utilization. Peak C increased in summer experiment units of all estuaries and decreased in other seasons, which coincides with the increase of SUVA 254 and UV slope in summer units discussed earlier.

We found that treatments (inorganic nutrient, salt addition and combination of these) did not effect the $\Delta(\%)$-values of CDOM or fluorescent DOM, which is in line with earlier results (Søndergaard et al., 2003) that showed low-salinity estuarine conditions to not influence the CDOM or fluorescent DOM composition or bioavailability of the whole DOM pool. Also the slight decrease in molecular size distribution during incubations was not significant $(P>0.05)$. This result suggests that the microbial activity did not alter the molecular size distribution, which is in contrast to other studies in which a linkage between DOM molecular size and its heterotrophic utilization has been established (e.g., Tranvik 1990; Amon and Benner, 1996). However, molecular size had an effect on the bacterial growth efficiency (Fig. 8), indicating differing energetic value to the heterotrophs along the DOM size spectrum (Kirchman, 2003).

\subsection{Impact of DOM quality to BGE}

There were significant differences in bacterial growth efficiency between estuaries (Fig. 7), and these covaried with the \%BDOC (Table 3), suggesting that the faster degradation of DOM and higher BGE resulted from the quality of DOM, i.e., its susceptibility to heterotrophic degradation (Fig. 8). BGE in the sea endmember experiment units was higher than in the river endmember waters. We hypothesize that lower BGE in rivers was due to the more refractory status of the riverine DOM compared to the DOM in the sea where DOM has already been exposed to a range of transformative forces (photo-oxidation, salt-induced changes, prolonged microbial activity), which are dynamic processes but result as a net increase of DOM reactivity. In conjunction with the gradual dilution and transformation of the terrestrial DOM in coastal waters, there is also an increase in the relative proportion of autochthonous DOM during mixing, which may explain these higher BGE values.

Season did not have an effect on BGE, suggesting that temperature did not affect BGE, which is surprising, since BGE is commonly accepted to be the inverse function of temperature (Rivkin and Legendre, 2001). Also, the seasonal changes in DOM quantity and quality evidently did not to affect BGE. Conversely, treatment (addition of inorganic nutrients, salt and combination of these) had an effect, more precisely the inorganic nutrient addition increased BGE. The positive effect of nutrient addition to BGE leads to assume 

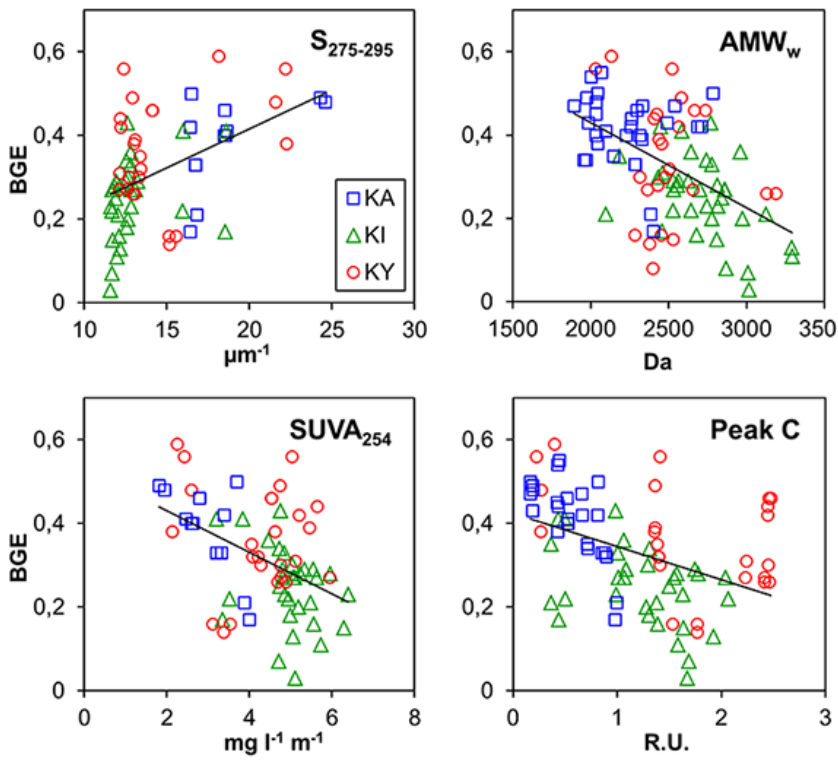

Fig. 8. Relationships between different DOM variables and BGE. AMW $\mathrm{W}_{\mathrm{W}}$ : apparent weight-averaged molecular weight, $S_{275-295}$ : slope coefficient between wavelengths 275 and $295 \mathrm{~nm}$, SUVA 254: carbon specific absorbance at $254 \mathrm{~nm}$, and peak $\mathrm{C}$ : humic-like fluorescence peak $\mathrm{C}$. Linear regression for the best-fit line describing relationships between slope BGE and AMWw: $y=-2.1 \times 10^{-4} \times+0.84, R^{2}=0.27, F=33.41$; $S_{275-295}: y=0.018 \times+0.43, R^{2}=0.23, F=20.59 ;$ SUVA $_{254}$ : $y=-0.050 \times+0.53, R^{2}=0.19, F=17.06$; and Peak C: $y=$ $-0.079 \times+0.42,<0.001$. Subsets indicate different estuaries: KA: Karjaanjoki, KI: Kiiminkijoki and KY: Kyrönjoki. Data are pooled from all experiments.

that increased inorganic nutrient availability reduces cost (less extracellular enzymes needed) of nutrient acquisition in general, or DON in other experiment units may have to be used as a source of nitrogen, which requires energy and decreases BGE (Hopkinson et al., 1997). Increased BGE in nutrient added units suggest that increased inorganic nutrient availability increases the amount of organic carbon transferred to the aquatic food web instead of respired $\mathrm{CO}_{2}$ (Pace et al., 2004; Kritzberg et al., 2006; Hitchcock et al., 2010).

Substrate concentrations have been observed to constrain BGE only in oligotrophic conditions (Eiler et al., 2003), and also in this study the DOC concentrations accounted for the slight variation in BGE $\left(R^{2}=0.14\right)$. Furthermore, there was no significant relationship between the amount of biodegradable DOC and BGE $(P=0.23)$. Instead, the quality of the DOM plays a crucial role in determining the BGE of the aquatic system, alongside with other factors such as inorganic nutrient availability and community assembly (Wikner et al., 1999; Berggren et al., 2007).

The DOM quality properties had significant, albeit weak to moderate relationships to BGE (Fig. 8). Molecular size (as measured by weight-averaged apparent molecular weight) had an inverse relationship to BGE; increasing molecular size led to decreasing BGE (concurring with Tulonen et al., 1992). This relationship arises from the differing quality of DOM along the size gradient, such as $\mathrm{C}: \mathrm{N}$ ratio decreasing with molecular size (Amon and Benner, 1996). BGE increased alongside increasing the UV slope $S_{275-295}$, which can be at least to some extent linked to decrease of refractory biopolymer, lignin (Fichot and Benner, 2012). The negative effect of aromatic, humic-like substances to BGE is supported by DOC-specific UV absorbance $\left(\mathrm{SUVA}_{254}\right)$ and humic-like fluorescence peak $\mathrm{C}$, which were both inversely related to BGE.

All in all, these properties of DOM that most affect BGE can be seen to represent different facets of the same general underlying denominator, as they all can be linked to aromaticity and humic-like characteristics. Humic substances, predominantly formed by the breakdown of terrestrially derived organic matter, dominate as a major carbon fraction in freshwater DOM (Dittmar and Kattner, 2003). They may account for over $80 \%$ of DOC leaching from agricultural soils, depending on the prevailing hydrological conditions (Waeles et al., 2013). Such humic substances are generally resistant to biodegradation in estuaries and the greatest changes in their quality and degradation only take place once they reach fully marine conditions (Kisand et al., 2013).

Our results are evidence that the qualitative parameters of DOM (molecular weight, spectral absorption and fluorescence properties) can better explain the variation in BGE instead of the quantitative parameters DOC or DON concentrations. There was variation in DOM quantity and quality throughout seasons studied, and bacterial community was still capable of processing the differing DOM with BGE of same level. Thus, we argue that either each bacterial community in the different estuaries was adapted to utilize differing substrates in varying conditions with unchanging BGE, or more likely, that there were seasonal changes in the community composition, which did not change the resulting BGE. The latter was shown by Langenheder et al., (2005), who found that BGE was determined by growth medium and not the adaptive capacity of the original bacterial community.

\section{Linking DOM quality and bacterial growth efficiency to $\mathrm{CO}_{2}$ emissions from estuaries}

Since BGE is a metric of the efficiency of a bacterial community to transfer carbon into biomass that is subsequently available for transfer into the food webs, we extrapolated the $\mathrm{CO}_{2}$ and bacterial biomass fluxes from the experimental data (Table 4). We also calculated fluxes for organic nitrogen by assuming a hypothetical nitrogen transfer efficiency of 1 , i.e., all utilized organic nitrogen being converted to bacterial biomass. This approach is justified by high DOC: DON uptake ratio and low BGE in the bioassays (Table 2, Fig. 7), 
Table 4. Daily $\mathrm{CO}_{2}$ fluxes and bacterial biomass generation from DOC and DON, and inferred biomass DOC: DON ratio in river and sea endmembers in each study estuary. Average BGE, BCD, DOC and DON concentrations, and $\mathrm{C}$ and $\mathrm{N}$ assimilation rates are derived from the results of this study. The range given in BGE values originates from different cell carbon content assumptions $\left(30.2 \pm 12.3 \mathrm{fg} \mathrm{C} \mathrm{Cell}^{-1}\right.$; Fukuda et al., 1998). With BCD and DOC values also a standard deviation of the averaged data set is given. $Q$ data is averaged over the whole study period from the SYKE HERTTA database (HERTTA, 2012). Water volume in sea endmember is equivalent to the river endmembers daily discharge for enabling direct comparison of these two. Range given in $\mathrm{CO}_{2}$ flux and bacterial biomass originates from different cell carbon coefficients. Refractory DOC and DON are the amounts not assimilated to bacterial biomass or respired (only DOC).

\begin{tabular}{|c|c|c|c|c|c|c|}
\hline \multirow{2}{*}{$\begin{array}{l}\text { Estuary } \\
\text { Endmember }\end{array}$} & \multicolumn{2}{|c|}{ Karjaanjoki } & \multicolumn{2}{|c|}{ Kiiminkijoki } & \multicolumn{2}{|c|}{ Kyrönjoki } \\
\hline & River & Sea & River & Sea & River & Sea \\
\hline BGE & $0.38 \pm 0.05$ & $0.45 \pm 0.05$ & $0.20 \pm 0.03$ & $0.31 \pm 0.05$ & $0.30 \pm 0.04$ & $0.48 \pm 0.04$ \\
\hline $\mathrm{BCD}\left(\mu \mathrm{mol} \mathrm{Cd} \mathrm{d}^{-1}\right)$ & $1.96 \pm 0.63$ & $2.10 \pm 0.63$ & $2.74 \pm 0.94$ & $1.40 \pm 0.60$ & $3.57 \pm 1.13$ & $3.06 \pm 4.57$ \\
\hline $\operatorname{DOC}\left(\mu \mathrm{mol} \mathrm{L}^{-1}\right)$ & $586 \pm 42$ & $352 \pm 64$ & $953 \pm 242$ & $401 \pm 29$ & $1273 \pm 230$ & $411 \pm 60$ \\
\hline$Q\left(\mathrm{Ls}^{-1}\right)$ & 15000 & 15000 & 44000 & 44000 & 37000 & 37000 \\
\hline DOC assimilation rate $\left(\mu \mathrm{mol} \mathrm{L} \mathrm{L}^{-1} \mathrm{~d}^{-1}\right)$ & 4.26 & 4.26 & 4.09 & 4.09 & 7.14 & 7.14 \\
\hline $\mathrm{CO}_{2}$ flux $\left(\mathrm{kg} \mathrm{Cd}^{-1}\right)$ & $41.1 \pm 3.0$ & $36.4 \pm 3.0$ & $149.3 \pm 4.7$ & $128.7 \pm 8.4$ & $191.7 \pm 9.6$ & $142.4 \pm 9.6$ \\
\hline Bacterial biomass $\left(\mathrm{kg} \mathrm{C} \mathrm{d}^{-1}\right)$ & $25.2 \pm 3.0$ & $29.8 \pm 3.0$ & $37.3 \pm 4.7$ & $57.8 \pm 8.4$ & $82.2 \pm 9.6$ & $131.5 \pm 9.6$ \\
\hline Refractory DOC $\left(\mathrm{kg} \mathrm{Cd}^{-1}\right)$ & 9050 & 5410 & 43300 & 18100 & 48600 & 15500 \\
\hline $\mathrm{DON}(\mu \mathrm{mol} \mathrm{L}-1)$ & 27.3 & 19.3 & 29.4 & 15.0 & 100.1 & 12.9 \\
\hline DON assimilation rate $\left(\mu \mathrm{mol} \mathrm{L}{ }^{-1} \mathrm{~d}^{-1}\right)$ & 0.23 & 0.23 & 0.08 & 0.08 & 0.62 & 0.62 \\
\hline Bacterial biomass $\left(\mathrm{kg} \mathrm{N} \mathrm{d}^{-1}\right)$ & 3.6 & 3.6 & 3.6 & 3.6 & 23.8 & 23.8 \\
\hline Refractory DON $\left(\mathrm{kg} \mathrm{N} \mathrm{d}^{-1}\right)$ & 421 & 297 & 1340 & 682 & 3820 & 472 \\
\hline Biomass DOC : DON & 7.0 & 8.3 & 10.2 & 15.8 & 3.5 & 5.5 \\
\hline
\end{tabular}

suggesting that excess carbon was utilized for sufficient energy and nitrogen uptake.

The carbon and nitrogen assimilation rates used in the calculations of parameters in Table 3 are derived from this study, using the daily average carbon and nitrogen degradation rates from the $\Delta(\%)$-values. Kiiminkijoki had the lowest assimilation rates for both carbon and nitrogen, and Kyrönjoki had the highest. The lower DOC degradation rate in the Kiiminkijoki units compared to the Kyrönjoki units does not necessarily indicate smaller quantity of bioavailable DOC in the whole DOC pool, but rather a slower utilization of it. This is likely to be due to variability in the quality (bioavailability) of DOM and the ability of each bacterial community to process the given DOM.

The average DOC:DON utilization ratio for the whole data set was 40, which is 6 to 7 times higher than typical $\mathrm{C}: \mathrm{N}$ ratios in bacterial cells in aquatic environments (Fukuda et al., 1998; Vrede et al., 2002). The inferred $\mathrm{C}: \mathrm{N}$ ratio in bacterial cells in this study deviates considerably from the DOC : DON uptake ratio, underlining the role of BGE in microbial carbon budgets. The biomass $\mathrm{C}: \mathrm{N}$ ratios ranged from 3.5 to 15.8 , average value being 8.4. For instance, Fukuda et al. (1998) reported a bacterial cell $\mathrm{C}: \mathrm{N}$ ratio of $5.9 \pm 1.1$ on average, and Vrede et al. (2002) estimated a $C: N$ ratio of $6.1 \pm 2.6$. However, the $\mathrm{C}: \mathrm{N}$ ratio is a highly variable parameter, e.g., different growth conditions and growth phases affect the ratio, and, in particular, nitrogen limitation increases the $\mathrm{C}: \mathrm{N}$ ratio (Vrede et al., 2002). When taking into account that a significant portion of carbon is respired as $\mathrm{CO}_{2}$ (esti- mated with BGE), the resulting inferred biomass $\mathrm{C}: \mathrm{N}$ ratio presented in Table 3 is well within the range of previous $C: N$ ratio estimates of bacterial biomass.

In all of the study estuaries, the higher BGE in the sea endmembers compared with the river endmembers resulted in a relatively higher proportion of carbon being transferred to biomass than to $\mathrm{CO}_{2}$ in the sea than in the river waters. However, in addition to the carbon dioxide originating from heterotrophic utilization of DOC estimated in this study, the total $\mathrm{CO}_{2}$ fluxes change significantly during estuarine transport due to e.g., physical changes in mixing zone, POC remineralization and varying primary production (Frankignoulle et al., 1998). In the system with the highest BGE, the Kyrönjoki sea endmember, almost equal amounts of carbon are transferred to biomass and $\mathrm{CO}_{2}, 132$ and $142 \mathrm{~kg} \mathrm{C} \mathrm{d}^{-1}$ respectively. The high rates of nitrogen assimilation also result in high amounts of $\mathrm{N}$ being transferred to bacterial biomass in the Kyrönjoki system compared to the other two estuaries. When comparing the $\mathrm{CO}_{2}$ fluxes from different estuaries, the differences in river discharge affect the volume-specific $\mathrm{CO}_{2}$ fluxes, ranging from $28 \mu \mathrm{g} \mathrm{C} \mathrm{L}^{-1}$ in the Karjaanjoki sea endmember to $60 \mu \mathrm{g} \mathrm{L}^{-1}$ in the Kyrönjoki river endmember. The relatively low assimilation rates throughout all systems means that the majority of the terrestrial DOC and DON is transported to the Baltic Sea, unaffected by the heterotrophic processes in the estuaries. 
Acknowledgements. This study was supported by the Academy of Finland (Finland Distinguished Professor Programme, project No. 127097) and the Walter and Andrée de Nottbeck Foundation. The authors would like to thank Chris Hulatt, Anne-Mari Luhtanen and Johanna Oja, for field and laboratory support. Support for sampling was also given by staff from the Tvärminne Zoological Station, South Ostrobothnia and North Ostrobothnia Centres for Economic Development, Transport and the Environment, and the Kiviniemi Association of Finnish Lifeboat Institution.

Edited by: S. W. A. Naqv and K. Suzuki

\section{References}

Abdulla, H. A. N., Minor, E. C., and Hatcher, P. G.: Using two dimensional correlations of 13C-NMR and FTIR to investigate changes in the chemical composition of dissolved organic matter along an estuarine transect, Environ. Sci. Technol., 44, 80448049, 2010.

Amon, R. M. W. and Benner, R.: Bacterial utilization of different size classes of dissolved organic matter, Limnol. Oceanogr., 41, 41-51, 1996.

Asmala, E., Stedmon, C. A., and Thomas, D. N.: Linking CDOM spectral absorption to dissolved organic carbon concentrations and loadings in boreal estuaries, Estuar. Coast. Shelf S., 111, 107-117, 2012.

Baker, A. and Spencer, R. G. M.: Characterization of dissolved organic matter from source to sea using fluorescence and absorbance spectroscopy, Sci. Total Environ., 333, 217-232, 2004.

Banoub, M. W.: Ultra-violet absorption as a measure of organic matter in natural waters in Bodensee, Arch. Hydrobiol., 71, 159165, 1973.

Berggren, M., Laudon, H., and Jansson, M.: Landscape regulation of bacterial growth efficiency in boreal freshwaters, Global Biogeochem. Cy., 21, GB4002, doi:10.1029/2006GB002844, 2007.

Berggren, M., Laudon, H., and Jansson, M.: Aging of allochthonous organic carbon regulates bacterial production in unproductive boreal lakes, Limnol. Oceanogr., 54, 1333-1342, 2009.

Bertilsson, S., Stepanauskas, R., Cuadros-Hansson, R., Graneli, W., Wikner, J., and Tranvik, L.: Photochemically induced changes in bioavailable carbon and nitrogen pools in a boreal watershed, Aquat. Microb. Ecol., 19, 47-56, 1999.

Bouvier, T. C. and del Giorgio, P. A.: Compositional changes in free-living bacterial communities along a salinity gradient in two temperate estuaries, Limnol. Oceanogr., 47, 453-470, 2002.

Bouvier, T., Del Giorgio, P. A., and Gasol, J. M.: A comparative study of the cytometric characteristics of high and low nucleicacid bacterioplankton cells from different aquatic ecosystems, Environ. Microbiol., 9, 2050-2066, 2007.

Boyd, T. J. and Osburn, C. L.: Changes in CDOM ?uorescence from allochthonous and autochthonous sources during tidal mixing and bacterial degradation in two coastal estuaries, Mar. Chem., 89, 189-210, 2004.

Boyer, J. N. and Groffman, P. M.: Bioavailability of water extractable organic carbon fractions in forest and agricultural soil profiles, Soil Biol. Biochem., 28, 783-790, 1996.

Brookshire, E. N. J., Valett, H. M., Thomas, S. A., and Webster, J. R.: Coupled cycling of dissolved organic nitrogen and carbon in a forest stream, Ecology, 86, 2487-2496, 2005.
Cammack, W. K. L., Kalff, J., Prairie, Y. T., and Smith, E. M.: Fluorescent dissolved organic matter in lakes: Relationships with heterotrophic metabolism, Limnol. Oceanogr., 49, 2034-2045, 2004.

Chin, Y. P., Aiken, G., and O'Loughlin, E.: Molecular Weight, Polydispersity, and Spectroscopic Properties of Aquatic Humic Substances, Environ. Sci. Technol., 28, 1853-1858, 1994.

Coble, P.: Characterization of marine and terrestrial DOM in seawater using excitation-emission matrix spectroscopy, Mar. Chem., 51, 325-346, 1996.

Cory, R. M., Crump, B. C., Dobkowski, J. A., and Kling, G. W.: Surface exposure to sunlight stimulates $\mathrm{CO}_{2}$ release from permafrost soil carbon in the Arctic. Proc. Nat. Acad. Sci., 110, 3429-3434, 2013.

del Giorgio, P. A. and Cole, J. J.: Bacterial growth efficiency in natural aquatic systems, Annu. Rev. Ecol. Syst., 29, 503-541, 1998.

Dittmar, T. and Kattner, G.: Recalcitrant dissolved organic matter in the ocean: major contribution of small amphiphilics, Mar. Chem., 82, 115-123, 2003.

Eiler, A., Langenheder, S., Bertilsson, S., and Tranvik, L. J.: Heterotrophic bacterial growth efficiency and community structure at different natural organic carbon concentrations, Appl. Environ. Microb., 69, 3701-3709, 2003.

Fagerbakke, K. M., Heldal, M., and Norland, S.: Content of carbon, nitrogen, oxygen, sulfur and phosphorus in native aquatic and cultured bacteria, Aquat. Microb. Ecol., 10, 15-27, 1996.

Fichot, C. and Benner, R.: A novel method to estimate DOC from CDOM absorption coefficients in coastal waters, Geophys. Res. Lett., 38, L03610, doi:10.1029/2010GL046152, 2011.

Fichot, C. and Benner, R.: The spectral slope coefficient of chromophoric dissolved organic matter (S275-295) as a tracer of terrigenous dissolved organic carbon in river-influenced ocean margins, Limnol. Oceanogr., 57, 1453-1466, 2012.

Frankignoulle, M., Abril, G., Borges, A., Bourge, I., Canon, C., Delille, B., Libert, E., and Théate, J.-M.: Carbon dioxide emission from European estuaries, Science, 282, 434-436, 1998.

Fuhrman, J. A. and Azam, F.: Bacterioplankton secondary production estimates for coastal waters of British Columbia, Antarctica and California, Appl. Environ. Microb., 39, 1085-1095, 1980.

Fukuda, R., Ogawa, H., Nagata, T., and Koike, I.: Direct determination of carbon and nitrogen content of natural bacterial assemblages in marine environments, Appl. Environ. Microb., 64, 3352-3358, 1998.

Gasol, J. M. and del Giorgio, P. A.: Using flow cytometry for counting natural planktonic bacteria and understanding the structure of planktonic bacterial communities, Sci. Mar., 64, 197-224, 2000.

Gasol, J. M., Zweifel, U. L., Peters, F., Fuhrman, J. A., and Hågström, A.: Significance of size and nucleic acid content heterogeneity as measured by flow cytometry in natural planktonic bacteria, Appl. Environ. Microb., 65, 4475-4483, 1999.

Grasshoff, K., Ehrhardt, M., and Kremling, K.: Methods of seawater analysis. 3rd Edn., Verlag Chemie $\mathrm{GmbH}$, Weinheim, 600 pp., 1999.

Guillemette, F., and del Giorgio, P. A.: Simultaneous consumption and production of fluorescent dissolved organic matter by lake bacterioplankton, Environ. Microbiol., 14, 1432-1443, 2012. 
Hansell, D. A. and Carlson, C. A.: Biogeochemistry of marine dissolved organic matter, Academic Press, San Diego, 774 pp., 2002

Hedges, J. I., Keil, R. G., and Benner, R.: What happens to terrestrial organic matter in the ocean, Org. Geochem., 27, 195-212, 1997.

Helms, J. R., Stubbins, A., Ritchie, J. D., Minor, E. C., Kieber, D. J., and Mopper, K.: Absorption spectral slopes and slope ratios as indicators of molecular weight, source, and photobleaching of chromophoric dissolved organic matter, Limnol. Oceanogr., 53, 955-969, 2008.

Hernes, P. J. and Benner, R.: Photochemical and microbial degradation of dissolved lignin phenols: Implications for the fate of terrigenous organic matter in marine systems, J. Geophys. Res.Oceans, 108, 3291, doi:10.1029/2002JC001421, 2003.

HERTTA: Finnish Environment Institute SYKE, HERTTA database, http://www.ymparisto.fi/default.asp?node= 14812\{\\&\}lan=en (last accesse: September 2012), 2012.

Hitchcock, J. N., Mitrovic, S., Kobayashi, T., and Westhorpe, D. P.: Responses of estuarine bacterioplankton, phytoplankton and zooplankton to dissolved organic carbon (DOC) and inorganic nutrient additions, Estuar. Coast., 33, 78-91, 2010.

Hopkinson, C. S., Fry, B., and Nolin, A.: Stoichiometry of dissolved organic matter dynamics on the continental shelf of the Northeastern USA, Cont. Shelf Res., 17, 473-489, 1997.

Hopkinson, C. S., Buffam, I., Hobbie, J., Vallino, J., Perdue, M., Eversmeyer, B., Prahl, F., Covert, J., Hodson, R., Moran, M., Smith, E., Baross, J., Crump, B., Findlay, S., and Foreman, K.: Terrestrial inputs of organic matter to coastal ecosystems: An intercomparison of chemical characteristics and bioavailability, Biogeochemistry, 43, 211-234, 1998.

Hulatt, C. J. and Thomas, D. N.: Dissolved organic matter (DOM) in microalgal photobioreactors: a potential loss in solar energy conversion?, Bioresource Technol., 101, 8690-8697, 2010.

Hulatt, C. J., Kaartokallio, H., Asmala, E., Autio, R. A., Stedmon, C. A., Sonninen, E., Oinonen, M., and Thomas, D. N.: Submitted. Microbial Degradation of Dissolved Organic Matter (DOM) from a northern peat dominated catchment, Aquatic Sciences, submitted, 2013.

Jiao, N., Herndl, G. J., Hansell, D. A., Benner, R., Kattner, G., Wilhelm, S. W., Kirchman, D. L., Weinbauer, M. G., Luo, T. W., Chen, F., and Azam, F.: Microbial production of recalcitrant dissolved organic matter: long-term carbon storage in the global ocean, Nature Rev. Microbiol., 8, 593-599, 2010.

Jickells, T. D.: Nutrient biogeochemistry of the coastal zone, Science, 281, 217-222, 1998.

Johnes, P., Moss, B., and Phillips, G.: The determination of total nitrogen and total phosphorus concentrations in freshwaters from land use, stock headage and population data: testing of a model for use in conservation and water quality management, Freshwater Biol., 36, 451-473, 1996.

Kähler, P. and Koeve, W.: Marine dissolved organic matter: can its $\mathrm{C}: \mathrm{N}$ ratio explain carbon overconsumption?, Deep-Sea Res. Pt. I, 48, 49-62, 2001

Kalbitz, K., Schmerwitz, J., Schwesig, D., and Matzner, E.: Biodegradation of soil-derived dissolved organic matter as related to its properties, Geoderma, 113, 273-291, 2003a.

Kalbitz, K., Schwesig, D., Schmerwitz, J., Kaiser, K., Haumaier, L., Glaser, B., Ellerbrock, R., and Leinweber, P.: Changes in proper- ties of soil-derived dissolved organic matter induced by biodegradation, Soil Biol. Biochem., 35, 1129-1142, 2003 b.

Kirchman, D. L.: The contribution of monomers and other lowmolecular weight compounds to the flux of dissolved organic material in aquatic ecosystems, in: Aquatic Ecosystems: Interactivity of Dissolved Organic Matter, Academic Press, San Diego, USA, 217-241, 2003.

Kirchman, D. L., Keil, R. G., and Wheeler, P. A.: The effect of amino acids on ammonium utilization and regeneration by heterotrophic bacteria in the subarctic Pacific, Deep-Sea Res., 36, 1763-1776, 1989.

Kisand, V., Gebhardt, S., Rullkötter, J., and Simon, M.: Significant bacterial transformation of riverine humic matter detected by pyrolysis GC-MS in serial chemostat experiments, Mar. Chem., 149, 23-31, 2013.

Koroleff, F.: Simultaneous persulphate oxidation of phosphorus and nitrogen compounds in water, In report of the Baltic Intercalibration Worshop, 52-53, 1977.

Kortelainen, P., Saukkonen, S., and Mattsson, T.: Leaching of nitrogen from forested catchments in Finland, Global Biogeochem. Cy., 11, 627-638, 1997.

Kortelainen, P., Mattsson, T., Finer, L., Ahtiainen, M., Saukkonen, S., and Sallantaus, T.: Controls on the export of C, N, P and Fe from undisturbed boreal catchments, Finland, Aquat. Sci., 68, 453-468, 2006.

Kritzberg, E. S., Cole, J. J., Pace, M. L., and Granéli, W.: Bacterial growth on allochthonous carbon in humic and nutrientenriched lakes: Results from whole-lake 13C addition experiments, Ecosystems, 9, 489-499, 2006.

Kroer, N.: Bacterial Growth Efficiency on Natural Dissolved Organic Matter, Limnol. Oceanogr., 38, 1282-1290, 1993.

Kuparinen, J. and Heinänen, A.: Inorganic nutrient and carbon controlled bacterioplankton growth in the Baltic Sea, Estuar. Coast. Shelf S., 37, 271-285, 1993.

Langenheder, S., Kisand, V., Wikner, J. and Tranvik, L. J.; Salinity as a structuring factor for the composition and performance of bacterioplankton degrading riverine DOC, FEMS Microbiol. Ecol., 45, 189-202, 2003.

Langenheder, S., Lindström, E. S., and Tranvik, L. J.: Weak coupling between community composition and functioning of aquatic bacteria, Limnol. Oceanogr., 50, 957-967, 2005.

Lee, S. and Fuhrman, J. D.: Relationships between biovolume and biomass of naturally derived marine bacterioplankton, Appl. Environ. Microb., 53, 1298-1303, 1987.

Lisitsyn, A. P.: The marginal filter of the ocean. Oceanology, 34, 671-682, 1995.

Lønborg, C., Davidson, K., Álvarez-Salgado, X. A., and Miller, A. E. J.: Bioavailability and bacterial degradation rates of dissolved organic matter in a temperate coastal area during an annual cycle, Mar. Chem., 113, 219-226, 2009.

Mann, K. H.: Production and use of detritus in various freshwater, estuarine, and coastal marine ecosystems, Limnol. Oceanogr., 33, 910-930, 1998.

Mann, P. J., Davidova, A., Zimov, N., Spencer, R. G. M., Davydov, S., Bulygina, E., Zimov, S., and Holmes, R. M.: Controls on the composition and lability of dissolved organic matter in Siberia's Kolyma River Basin, J. Geophys. Res.-Biogeo., 117, G01028, doi:10.1029/2011JG001798, 2012. 
Mattsson, T., Kortelainen, P., and Räike, A.: Export of DOM from boreal catchments: Impacts of land use cover and climate, Biogeochemistry, 76, 373-394, 2005.

McDowell, W. H., Magill, A., Aitkenhead-Peterson, J. A., Aber, J. D., Merriam, J., and Kaushal, S.: Effects of chronic nitrogen amendment on dissolved organic matter and inorganic nitrogen in soil solution. Forest Ecology and Management, 196, 29-42, 2004.

McKnight, D. M., Boyer, E. W., Westerhoff, P. T., Doran, P. T., Kulbe, T., and Anderson, D. T.: Spectrofluorometric characterization of dissolved organic matter for indication of precursor organic material and aromaticity, Limnol. Oceanogr., 46, 38-48, 2001.

Mobed, J. J., Hemmingsen, S. L., Autry, J. L., and McGown, L. B.: Fluorescence characterization of IHSS humic substances: Total luminescence spectra with absorbance correction, Environ. Sci. Technol., 30, 3061-3065, 1996.

Moran, M. A. and Hodson, R. E.: Bacterial production on hurnic and non-humic components of dissolved organic carbon, Limnol. Oceanogr., 35, 1744-1756, 1990.

Nayar, S. and Chou, L. M.: Relative ef?ciencies of different ?ters in retaining phytoplankton for pigment and productivity studies, Estuar. Coast. Shelf S., 58, 241-248, 2003.

Nelson, N. B. and Siegel, D. A.: The global distribution and dynamics of chromophoric dissolved organic matter, Annual Review of Marine Science, 5, 447-476, 2013.

Nelson, N. B., Carlson, C. A., and Steinberg, D. K.: Production of chromophoric dissolved organic matter by Sargasso Sea microbes, Mar. Chem., 89, 273-287, 2004.

Opsahl, S. and Benner, R.: Distribution and cycling of terrigenous dissolved organic matter in the ocean, Nature, 386, 480-482, 1997.

Ortega-Retuerta, E., Frazer, T. K., Duarte, C. M., Ruiz, S., TovarSánchez, A., Arrieta, J. M., and Reche, I.: Biogeneration of chromophoric dissolved organic matter by bacteria and krill in the Southern Ocean, Limnol. Oceanogr., 54, 1941-1950, 2009.

Pace, M. L., Cole, J. J., Carpenter, S. R., Kitchell, J. F., Hodgson, J. R., Van de Bogert, M. C., Bade, D. L., Kritzberg, E. S., and Bastviken, D.: Whole-lake carbon-13 additions reveal terrestrial support of aquatic food webs, Nature, 427, 240-24, 2004.

Prairie, Y. T.: Evaluating the predictive power of regression models, Can. J. Fish. Aquat. Sci., 53, 490-492, 1996.

Qian, J-G. and Mopper, K.: Automated high-performance, hightemperature combustion dissolved organic carbon analyzer, Anal. Chem., 68, 3090-3097, 1996.

R Core Team: R: A language and environment for statistical computing. R Foundation for Statistical Computing, Vienna, Austria, ISBN 3-900051-07-0, http://www.R-project.org/, 2013.

Riemann, B., Bjornsen, P. K., Newell, S., and Fallon, R.: Calculation of cell production of coastal marine bacteria based on measured incorporation of 3H-thymidine, Limnol. Oceanogr., 32, 471-476, 1987.

Rivkin, R. B., Legendre, L.: Biogenic carbon cycling in the upper ocean: Effects of microbial respiration, Science, 291, 23982400, 2001.

Sachse, A., Henrion, R., Gelbrecht, J., and Steinberg, C.: Classification of dissolved organic carbon (DOC) in river systems: Influence of catchment characteristics and autochthonous processes, Org. Geochem., 36, 923-935, 2005.
Shimotori, K., Watanabe, K., and Hama, T.: Fluorescence characteristics of humic-like fluorescent dissolved organic matter produced by various taxa of marine bacteria, Aquat. Microb. Ecol., 65, 249-260, 2012.

Sholkovitz, E. R., Boyle, E. A., and Price, N. B.: The removal of dissolved humic acids and iron during estuarine mixing, Earth Planet. Sc. Lett., 40, 130-136, 1978.

Simon, M. and Azam, F.: Protein content and protein synthesis rates of marine bacterial assemblages, Mar. Ecol.-Prog. Ser., 34, 4149, 1989.

Sintes, E., Stoderegger, K., Parada, V., and Herndl, G. J.: Seasonal dynamics dissolved organic matter and microbial activity in the coastal North Sea, Aquat. Microb. Ecol., 60, 85-95, 2010.

Søndergaard, M. and Middelboe, M.: A cross-system analysis of labile dissolved organic carbon (DOC-L), Mar. Ecol.-Prog. Ser., 118, 283-294, 1995.

Søndergaard, M. and Thomas, D. N. (eds.): Dissolved organic matter (DOM) in aquatic ecosystems. A study of European catchments and coastal waters, The DOMAINE project, 72 pp., 2004.

Søndergaard, M., Stedmon, C. A., and Borch, N. H.: Fate of terrigenous dissolved organic matter (DOM) in estuaries: Aggregation and bioavailability, Ophelia, 57, 161-176, 2003.

Stedmon, C. A. and Markager, S.: The optics of chromophoric dissolved organic matter (CDOM) in the Greenland Sea: An algorithm for differentiation between marine and terrestrially derived organic matter, Limnol. Oceanogr., 46, 2087-2093, 2001.

Stedmon, C. A. and Markager, S. S.: Tracing the production and degradation of autochthonous fractions of dissolved organic matter by fluorescence analysis, Limnol. Oceanogr., 50, 1415-1426, 2005.

Stedmon, C. A., Markager, S., and Kaas, H.: Optical properties and signatures of chromophoric dissolved organic matter (CDOM) in Danish coastal waters, Estuar. Coast. Shelf S., 51, 267-278, 2000.

Stedmon, C. A., Markager, S. S., Søndergaard, M., Vang, T., Laubel, A., Borch, N., and Windelin, A.: Dissolved organic matter (DOM) export to a temperate estuary: Seasonal variations and implications of land use, Estuaries Coasts, 29, 388-400, 2006.

Sun, L., Perdue, E. M., Meyer, J. L., and Weis, J.: Use of elemental composition to predict bioavailability of dissolved organic matter in a Georgia river, Limnol. Oceanogr., 42, 714-72, 1997.

Tranvik, L. J.: Bacterioplankton growth on different molecular weight fractions of dissolved organic carbon from humic and clear waters, Appl. Environ. Microb., 56, 1672-1677, 1990.

Tulonen, T., Salonen, K., and Arvola, L.: Effects of different molecular weight fractions of dissolved organic matter on the growth of bacteria, algae and protozoa from a highly humic lake, Hydrobiologia 229, 239-252, 1992.

van Kessel, C., Clough, T., and van Groenigen, J. W.: Dissolved organic nitrogen: An overlooked pathway of nitrogen loss from agricultural systems?, J. Environ. Quality, 38, 393-401, 2009.

Vartiainen, T., Liimatainen, A., and Kauranen, P.: The use of TSK size exclusion columns in determination of the quality and quantity of humus in raw waters and drinking waters, Sci. Total Environ., 62. 75-84, 1987.

Vitousek, P. M., Aber, J. D., Howarth, R. W., Likens, G. E., Matson, P. A., Schindler, D. W., Schlesinger, W. H., and Tilman, D.: Human alteration of the global nitrogen cycle: sources and consequences, Ecol. Appl., 7, 737-750, 1997. 
Vrede, K., Heldal, M., Norland, S., and Bratbak, G.: Elemental composition $(\mathrm{C}, \mathrm{N}, \mathrm{P})$ and cell volume of exponentially growing and nutrient-limited bacterioplankton, Appl. Environ. Microb., 68, 2965-2971, 2001.

Waeles, M., Riso, R., Pernet-Coudrier, B., Quentel, F., Durrieu, G., and Tissot, C.: Annual cycle of humic substances in a temperate estuarine system affected by agricultural practices, Geochim. Cosmochim. Ac., 106, 231-246, 2013.

Weishaar, J. L., Aiken, G. R., Bergamaschi, B. A., Fram, M. S., Fujii, R., and Mopper, K.: Evaluation of Specific Ultraviolet Absorbance as an Indicator of the Chemical Composition and Reactivity of Dissolved Organic Carbon, Environ. Sci. Technol., 37, 4702-4708, 2003.
Weiss, M. and Simon, M.: Consumption of labile dissolved organic matter by limnetic bacterioplankton: the relative significance of amino acids and carbohydrates, Aquat. Microb. Ecol., 17, 1-12, 1999.

Wikner, J., Cuadros, R., and Jansson, M.: Differences in consumption of allochthonous DOC under limnic and estuarine conditions in a watershed, Aquat. Microb. Ecol., 17, 289-299, 1999.

Zweifel, U. L., Wikner, J., Hagström, A., Lundberg, E., and Norrman, B.: Dynamics of dissolved organic carbon in a coastal ecosystem, Limnol. Oceanogr., 40, 299-305, 1995. 